\title{
Surface-circulation change in the southwest Pacific Ocean across the Middle Eocene Climatic Optimum: inferences from dinoflagellate cysts and biomarker paleothermometry
}

\author{
Margot J. Cramwinckel ${ }^{1, a}$, Lineke Woelders ${ }^{1, b}$, Emiel P. Huurdeman ${ }^{2}$, Francien Peterse ${ }^{1}$, Stephen J. Gallagher ${ }^{3}$, \\ Jörg Pross ${ }^{2}$, Catherine E. Burgess ${ }^{4, c}$, Gert-Jan Reichart ${ }^{1,5}$, Appy Sluijs ${ }^{1}$, and Peter K. Bijl ${ }^{1}$ \\ ${ }^{1}$ Department of Earth Sciences, Faculty of Geoscience, Utrecht University, Utrecht, the Netherlands \\ ${ }^{2}$ Paleoenvironmental Dynamics Group, Institute of Earth Sciences, Heidelberg University, Heidelberg, Germany \\ ${ }^{3}$ School of Earth Sciences, The University of Melbourne, Melbourne, Australia \\ ${ }^{4}$ School of Earth and Ocean Sciences, Cardiff University, Cardiff, UK \\ ${ }^{5}$ NIOZ Royal Netherlands Institute for Sea Research, and Utrecht University, Den Burg, Texel, the Netherlands \\ ${ }^{a}$ now at: School of Ocean and Earth Science, National Oceanography Centre Southampton, \\ University of Southampton, Southampton, UK \\ ${ }^{\mathrm{b}}$ now at: Cooperative Institute for Research in Environmental Sciences, Western Water Assessment, \\ University of Colorado Boulder, Boulder, CO, USA \\ ${ }^{c}$ now at: Shell UK Ltd, Aberdeen, UK
}

Correspondence: Margot J. Cramwinckel (m.j.cramwinckel@soton.ac.uk)

Received: 18 March 2019 - Discussion started: 4 April 2019

Revised: 15 May 2020 - Accepted: 16 June 2020 - Published: 1 September 2020

\begin{abstract}
Global climate cooled from the early Eocene hothouse $(\sim 52-50 \mathrm{Ma})$ to the latest Eocene $(\sim 34 \mathrm{Ma})$. At the same time, the tectonic evolution of the Southern Ocean was characterized by the opening and deepening of circumAntarctic gateways, which affected both surface- and deepocean circulation. The Tasmanian Gateway played a key role in regulating ocean throughflow between Australia and Antarctica. Southern Ocean surface currents through and around the Tasmanian Gateway have left recognizable tracers in the spatiotemporal distribution of plankton fossils, including organic-walled dinoflagellate cysts. This spatiotemporal distribution depends on both the physicochemical properties of the water masses and the path of surface-ocean currents. The extent to which climate and tectonics have influenced the distribution and composition of surface currents and thus fossil assemblages has, however, remained unclear. In particular, the contribution of climate change to oceanographic changes, superimposed on long-term and gradual changes induced by tectonics, is still poorly understood.
\end{abstract}

To disentangle the effects of tectonism and climate in the southwest Pacific Ocean, we target a climatic deviation from the long-term Eocene cooling trend: the Middle Eocene Climatic Optimum (MECO; $\sim 40 \mathrm{Ma}$ ). This $500 \mathrm{kyr}$ phase of global warming was unrelated to regional tectonism, and thus provides a test case to investigate the ocean's physicochemical response to climate change alone. We reconstruct changes in surface-water circulation and temperature in and around the Tasmanian Gateway during the MECO through new palynological and organic geochemical records from the central Tasmanian Gateway (Ocean Drilling Program Site 1170), the Otway Basin (southeastern Australia), and the Hampden Beach section (New Zealand). Our results confirm that dinocyst communities track specific surface-ocean currents, yet the variability within the communities can be driven by superimposed temperature change. Together with published results from the east of the Tasmanian Gateway, our new results suggest a shift in surface-ocean circulation during the peak of MECO warmth. Simultaneous with high sea-surface temperatures in the Tasmanian Gateway area, pollen assem- 
blages indicate warm temperate rainforests with paratropical elements along the southeastern margin of Australia. Finally, based on new age constraints, we suggest that a regional southeast Australian transgression might have been coincident with the MECO.

\section{Introduction}

The Eocene epoch ( 56-34 Ma, millions of years ago) was characterized by gradual ocean cooling from the early Eocene hothouse ( 52-50 Ma) to the early Oligocene icehouse (33 Ma), accompanied by decreasing atmospheric $\mathrm{CO}_{2}$ concentrations (Zachos et al., 2008; Inglis et al., 2015; Anagnostou et al., 2016; Cramwinckel et al., 2018). In the framework of Eocene climate evolution, the Southern Ocean (SO) and its circulation are of particular interest. Geochemical tracers (Thomas et al., 2003; Huck et al., 2017) and model simulations using specific Eocene boundary conditions $\mathrm{(Hu}-$ ber and Caballero, 2011) indicate that the SO, and the southwest Pacific Ocean (SWP) in particular (Sijp et al., 2014; Baatsen et al., 2020), was the main source of intermediateand deep-water formation during the early Paleogene. This effectively relays SO surface conditions to the global deep ocean. Several sites from the SWP sector of the SO have yielded proxy-based sea-surface temperatures (SSTs) (Bijl et al., 2009; Hollis et al., 2009, 2012) that are 5-10 ${ }^{\circ} \mathrm{C}$ higher than the temperatures derived from the current generation of fully coupled climate models (Huber and Caballero, 2011; Lunt et al., 2012; Cramwinckel et al., 2018). These high seawater temperatures are supported by biomarker-based continental air-temperature estimates and vegetation reconstructions on the surrounding continents that indicate paratropical conditions (Pross et al., 2012; Carpenter et al., 2012; Contreras et al., 2013, 2014), although land and ocean temperatures did not necessarily change synchronously in this region (Pancost et al., 2013). This mismatch between proxy- and model-based temperatures has remained a conundrum.

As a result of tectonic processes, the bathymetry and geography of the Southern Ocean experienced major reorganizations in the Eocene (Kennett et al., 1974; Cande and Stock, 2004) that strongly affected regional and global ocean circulation (Huber et al., 2004; Sijp et al., 2014) (Fig. 1). In the earliest Eocene, the Australian and South American continents were much closer to Antarctica (e.g., Cande and Stock, 2004) and obstructed circum-Antarctic ocean circulation. Instead, subpolar gyres dominated circulation patterns in the southern sectors of the Indian Ocean and Pacific Ocean, transporting relatively warm surface waters to the Antarctic coast (Huber et al., 2004; Sijp et al., 2011; Baatsen et al., 2020) (Fig. 1a). Tectonic activity in the Eocene led to the opening and subsequent deepening of the Tasmanian Gateway (TG; Stickley et al., 2004b; Bijl et al., 2013b) and Drake Passage (Scher and Martin, 2004; Lagabrielle et al., 2009). Furthermore, a transition from northwesterly to accelerated northerly displacement of the Australian continent (Cande and Stock, 2004; Hill and Exon, 2004; Williams et al., 2019) and post-rift collapse of the outer continental shelf on both the Australian and Antarctic margins (Totterdell et al., 2000; Close et al., 2009) occurred. Subduction initiation affected vertical motion of submerged parts of northwestern Zealandia including the Lord Howe Rise in the Tasman Sea (Sutherland et al., 2017, 2020). This complex tectonic evolution should have affected ocean circulation and, in turn, heat transport and regional climate.

Along with the indirect inferences from modeling and heat distribution based on SST reconstructions, biogeographic patterns of surface-water plankton may be used as a tool to reconstruct surface-ocean circulation. In the Paleogene SO, high levels of endemism characterize a diverse range of fossil groups, including mollusks (Zinsmeister, 1979), radiolarians and diatoms (Harwood, 1991; Lazarus et al., 2008; Pascher et al., 2015), calcareous nannoplankton and planktonic foraminifera (Nelson and Cooke, 2001; Villa et al., 2008), and organic-walled dinoflagellate cysts (dinocysts) (Wrenn and Beckman, 1982; Wrenn and Hart, 1988; Bijl et al., 2011, 2013a). The endemic dinocyst assemblage from the SO is traditionally referred to as "Transantarctic Flora" (Wrenn and Beckman, 1982). Here, following more recent extensive biogeographic mapping (Huber et al., 2004; Warnaar et al., 2009; Bijl et al., 2011, 2013b), we use these "Antarctic endemic dinocysts" to track Antarctica-derived surface currents, while we use cosmopolitan assemblages to track currents sourced from the low latitudes. Throughout the Eocene, the Australian margin of the Australo-Antarctic Gulf (AAG) and New Zealand east of the Tasman Sea were characterized by high percentages of cosmopolitan dinocysts, implying an influence of the low-latitude-sourced ProtoLeeuwin Current (PLC) and the East Australian Current (EAC), respectively (Fig. 1). In contrast, coeval assemblages on the eastern side of the Tasmanian Gateway were endemic to Antarctica, showing the influence of the Antarcticaderived northward-flowing Tasman Current (TC) (Huber et al., 2004; Bijl et al., 2011, 2013b). From about 50 Ma onwards, endemic dinocyst assemblages were established on both the Antarctic margin in the Australo-Antarctic Gulf and the eastern boundaries of the Tasmanian Gateway and Drake Passage (Bijl et al., 2011, 2013b). This indicates surficial westward flow through the Tasmanian Gateway of a protoAntarctic Counter Current (proto-ACC), which is supported by simulations using an intermediate-complexity coupled model (Sijp et al., 2016). Pronounced widening and deepening of the gateway did not start until the late Eocene (Stickley et al., 2004b), although some subsidence already took place during the middle Eocene (Röhl et al., 2004).

These biogeographical patterns broadly confirm the $\mathrm{Pa}-$ leogene ocean circulation patterns as simulated by numerical climate models (Huber et al., 2004). Thus, on tectonic timescales (i.e., tens of millions of years), plankton biogeographical patterns predominantly follow changes in surface- 


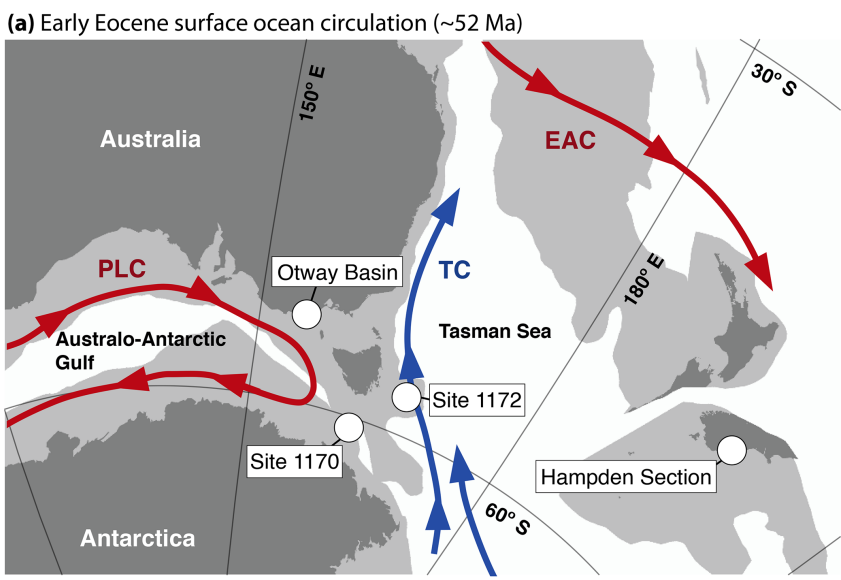

(b) Middle Eocene surface ocean circulation ( 41 or 39 Ma)

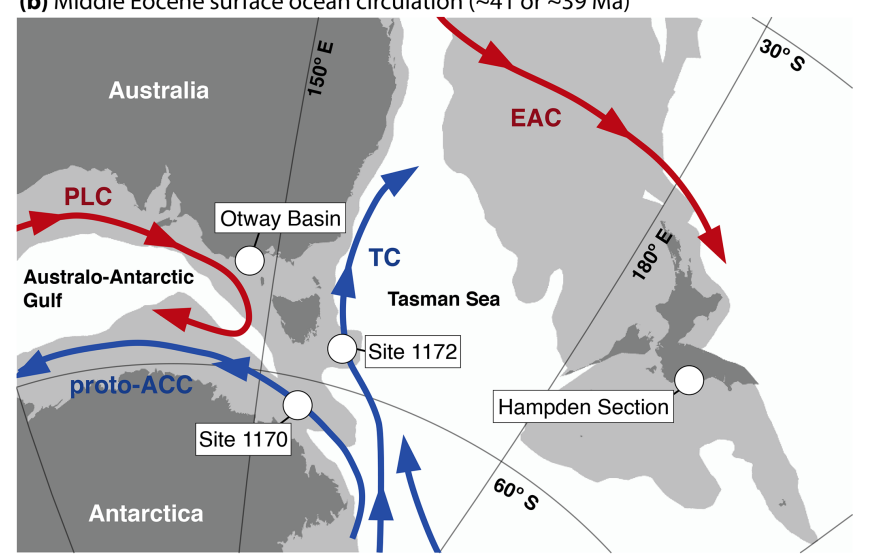

(c) Peak MECO surface ocean circulation scenarios ( 40 Ma)

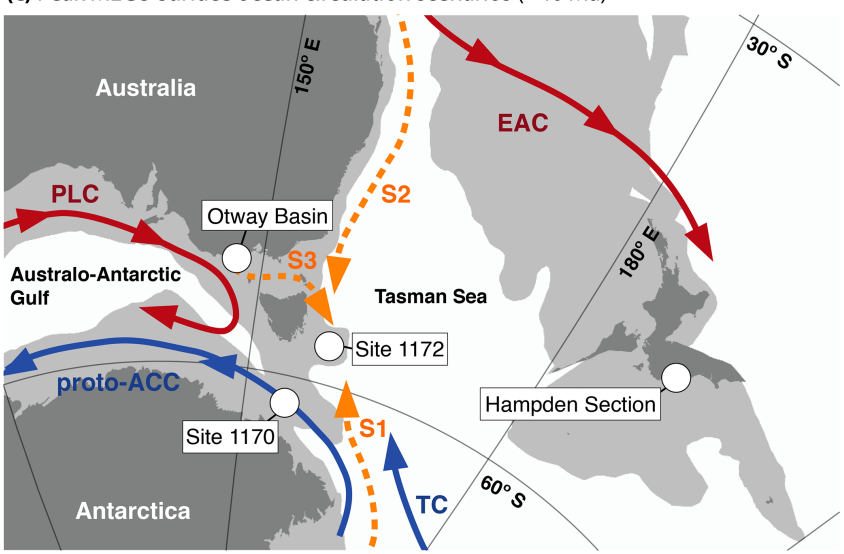

Figure 1. Inferred generalized Eocene surface-ocean circulation patterns in the southwest Pacific Ocean based on dinocyst biogeographic patterns. (a) Generalized early Eocene ( $\sim 52 \mathrm{Ma})$ surface-ocean circulation. (b) Generalized middle Eocene surface-ocean circulation preMECO ( $\sim 41 \mathrm{Ma}$ ) and post-MECO ( $39 \mathrm{Ma})$. (c) Three potential surface-ocean circulation scenarios (S1, S2, and S3) for peak MECO ( $\sim 40 \mathrm{Ma}$ ) based on dinocyst assemblage constraints (cf. Sect. 5.1). Maps constructed with GPlates, using Torsvik et al. (2012) paleomagnetic rotation frame and Matthews et al. (2016) continental polygons, and coastlines for $52 \mathrm{Ma}$ (a) and $40 \mathrm{Ma}$ (b and c). Note that, within this rotation frame, there is uncertainty in the drawn paleolatitudes. For example, Site 1170 is drawn at $61.6^{\circ} \mathrm{S}$ at $40 \mathrm{Ma}$, but the uncertainty margins on this are between 58.76 and $64.55^{\circ} \mathrm{S}$ (van Hinsbergen et al., 2015). Currents drawn after reconstructions by Bijl et al. (2011, 2013a, b) and this study. EAC represents East Australian Current; PLC represents Proto-Leeuwin Current; TC represents Tasman Current; and proto-ACC represents proto-Antarctic Counter Current. 
ocean circulation (Bijl et al., 2011). During periods with a relatively stable ocean-current configuration, such as the middle Eocene, SO dinocyst assemblage variability was instead driven by (orbital-scale; Warnaar et al., 2009) climatic factors such as SST (Bijl et al., 2011). Superimposed changes in SWP dinocyst assemblages also occur during transient climate change such as the Paleocene-Eocene Thermal Maximum (PETM, $\sim 56 \mathrm{Ma}$; Sluijs et al., 2011) and the Middle Eocene Climatic Optimum (MECO, $40 \mathrm{Ma}$; Bijl et al., 2010). During the PETM, global warming of $\sim 5^{\circ} \mathrm{C}$ occurred within millennia, associated with the injection of a large mass of reduced carbon into the ocean-atmosphere system, which resulted in the appearance of tropical dinocyst taxa at the East Tasman Plateau (Sluijs et al., 2011). In contrast, although with similar magnitude of warming, the MECO was a $500 \mathrm{kyr}$ (thousand year) period of transient warming of the global deep ocean (Bohaty et al., 2009; Bohaty and Zachos, 2003) and surface ocean (Boscolo-Galazzo et al., 2014; Cramwinckel et al., 2018). Regionally, the MECO was associated with changes in oceanic productivity and oxygenation, reflected by changes in planktic and benthic assemblages (e.g., Spofforth et al., 2010; BoscoloGalazzo et al., 2015; Cramwinckel et al., 2019). However, the mechanism that caused MECO warming remains enigmatic. Deep-ocean carbonate dissolution (Bohaty et al., 2009), indications for $p \mathrm{CO}_{2}$ rise (Bijl et al., 2010; Steinthorsdottir et al., 2019; Henehan et al., 2020), and a diminished weathering feedback (van der Ploeg et al., 2018) during the MECO imply that climate change was forced by an accumulation of carbon in the exogenic carbon pool. The lack of a negative trend in stable carbon isotope ratios $\left(\delta^{13} \mathrm{C}\right)$ over the MECO suggests this carbon to be volcanic, rather than organic, in origin (Bohaty et al., 2009). One of the proposed MECO carboncycle scenarios suggests a global sea-level rise in order to shift the locus of carbonate deposition from the deep ocean to the continental shelves (Sluijs et al., 2013). Although speculative isotopic evidence for a MECO-associated change in glacioeustasy exists (Dawber et al., 2011), constraints on global sea-level change during the MECO are lacking. At the East Tasman Plateau, the MECO is characterized by an incursion of low-latitude dinocyst taxa that temporarily replaced the largely endemic Antarctic community (Bijl et al., 2010). The origin of these cosmopolitan dinocysts remains an unresolved question. Potentially, cosmopolitan dinoflagellates outcompeted the Antarctic endemic taxa in the warming TC, similar to during the PETM. Alternatively, a southward extension of the EAC from the north or leakage of the PLC from the west through the Tasmanian Gateway supplied cosmopolitan assemblages to the region east of Tasmania, possibly even associated with sea-level rise.

To disentangle the effects of tectonism and climate change in the southwest Pacific Ocean, we here assess the biotic and oceanographic response in that region to MECO warming. The MECO allows us to assess oceanographic response to climate change, independent of tectonic change. We recon- struct surface-ocean circulation and temperature by generating new dinocyst and organic geochemical records from Ocean Drilling Program (ODP) Site 1170 on the South Tasman Rise in the central Tasmanian Gateway. We place these records into their broader regional context by comparing them to newly generated middle Eocene palynological records, including pollen from terrestrial plants, from the Otway Basin (SE Australia) and the Hampden Beach section (New Zealand) (Fig. 2a).

\section{Material}

\subsection{South Tasman Rise (ODP Site 1170) and East Tasman Plateau (ODP Site 1172)}

Ocean Drilling Program Site 1170 is located at a water depth of $\sim 2704 \mathrm{~m}, 400 \mathrm{~km}$ south of Tasmania at $47.1507^{\circ} \mathrm{S}$, $146.0498^{\circ} \mathrm{E}$ (Exon et al., 2001) (Fig. 2a). It was drilled on the western side of the South Tasman Rise (STR), a continental block to the south of present-day Tasmania. The site is located in a $2-3 \mathrm{~km}$ deep and $50 \mathrm{~km}$ wide graben within the Ninene Basin (Fig. 2b). An $\sim 300 \mathrm{~m}$ thick package of shallow marine silty claystones of middle Eocene age overlies an erosional unconformity. Northwest-southeast rifting between Australia and Antarctica accelerated after $51 \mathrm{Ma}$, resulting in prominent NW-SE structural trends in seabed seismic topography associated with seafloor spreading between Tasmania-STR on the one side and Antarctica on the other (Exon et al., 2004; Bijl et al., 2013b; Williams et al., 2019) (Fig. 2a). This coincided with renewed subsidence of both conjugate continental margins (Totterdell et al., 2000) and the STR (Hill and Exon, 2004). Marked lateral thinning of middle Eocene deposits at Site 1170 is apparent in the seismic profile, suggesting synsedimentary growth faulting caused local subsidence (Fig. 2c). Middle Eocene sediments are present in Hole 1170D as a thick sequence from $\sim 500 \mathrm{~m}$ below sea floor (mb.s.f.) to the total depth at $780 \mathrm{mb}$.s.f. (Exon et al., 2001). The precise age of the middle Eocene strata at Site 1170 has thus far not been well constrained (Stickley et al., 2004a). Nevertheless, the thickness of the middle Eocene sequence implies high sedimentation rates (Exon et al., 2001), together with the seismic evidence suggesting that the surrounding graben was a depocenter that formed as rifting developed. Middle Eocene sediments are overlain by latest Eocene to earliest Oligocene glauconiterich clayey siltstones (Exon et al., 2001; Sluijs et al., 2003; Stickley et al., 2004a). Here, we target the middle Eocene claystones from the interval $\sim 500-780 \mathrm{~m}$ b.s.f. for dinocyst biogeography and organic geochemistry to gain a central Tasmanian Gateway perspective on regional effects of the MECO.

Ocean Drilling Program Site 1172 is located at a water depth of $\sim 2620 \mathrm{~m}$ on thinned continental crust on the western side of the East Tasman Plateau (ETP), $\sim 170 \mathrm{~km}$ southeast of Tasmania at $43.9598^{\circ} \mathrm{S}, 149.9283^{\circ} \mathrm{E}$ (Exon et al., 


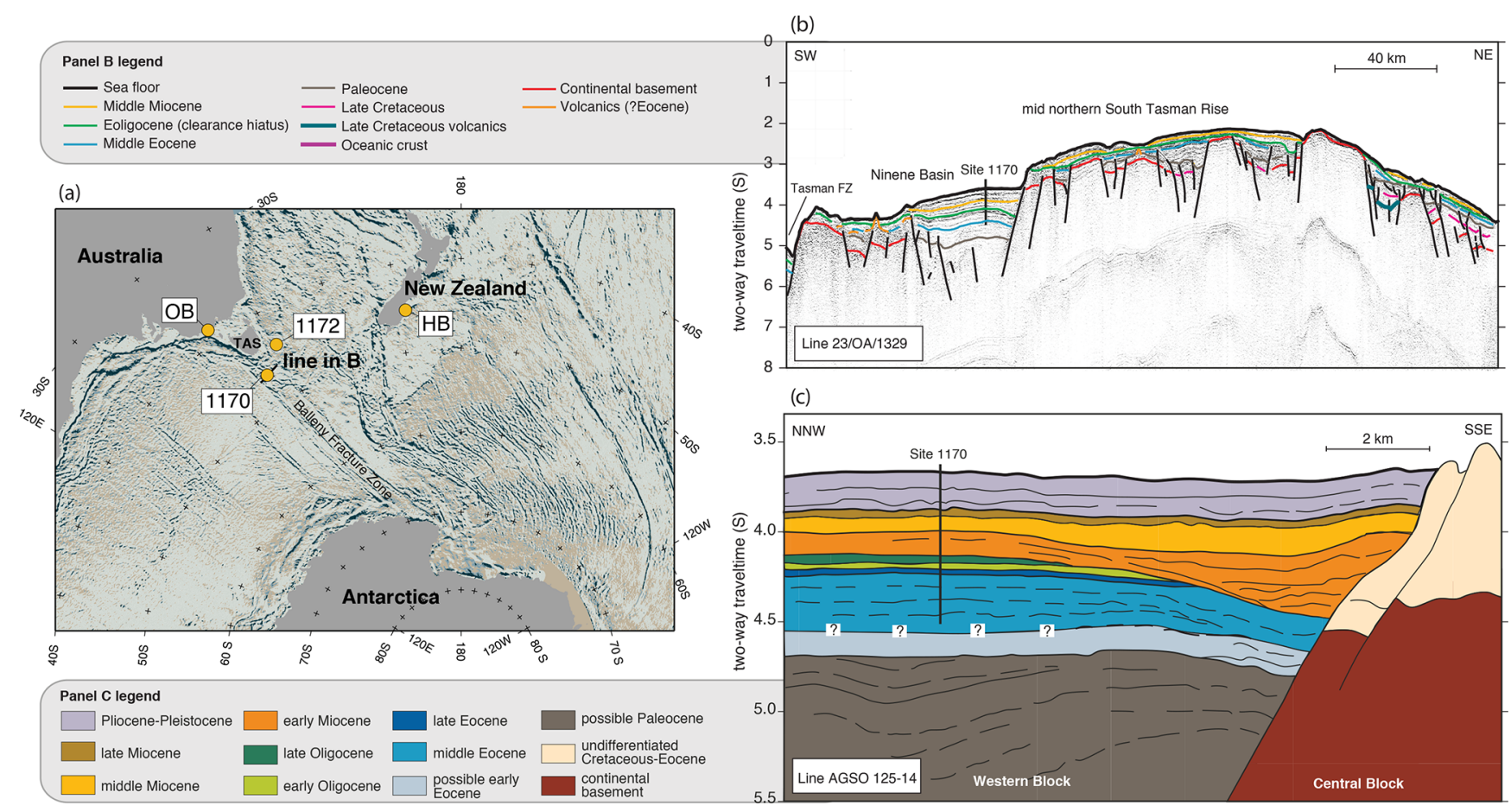

Figure 2. Tectonic setting of ODP Site 1170 and other studied sites. (a) Present-day map of the Australo-Antarctic sector of the Southern Ocean, with present-day locations of sites and sections used in this study as yellow circles (ODP Site 1170; ODP Site 1172; OB, Otway Basin; HB, Hampden Beach). NW-SE structural trends mark the direction of rifting between Australia and Antarctica, clearly visible in the (labeled) Balleny Fracture Zone. Seismic profile line 23/OA/1329, as shown in panel (b), is drawn as a thick black line. Seismic profile line AGSO125-14 is not drawn due to its small scale. Adapted from Bijl et al. (2013b) and Cande and Stock (2004). (b) Interpreted SW-NE seismic profile (line SO36-58) across the South Tasman Rise, illustrating the Site 1170 location in a graben structure. Profile and interpretation adapted from Hill and Moore (2001). (c) Interpreted NNW-SSE seismic profile (line AGSO125-14) across the South Tasman Rise, including Site 1170, illustrating laterally thinning seismic layers of interpreted middle Eocene age. Profile and interpretation adapted from Exon et al. (2001).

2001) (Fig. 2a). While the ETP has a similar tectonic history to the STR, Site 1172 was not affected by growth faulting and subsidence like Site 1170 during the middle Eocene (Hill and Moore, 2001). Palynological and organic geochemical results for the middle Eocene of the East Tasman Plateau are presented in Bijl et al. (2009, 2010, 2011, 2013a), and are compared to our results from the South Tasman Rise in this study.

\subsection{Latrobe-1 borehole, Otway Basin (Australo-Antarctic Gulf, southeast Australia)}

Sediment cores from the Otway Basin, on the Australian margin of the AAG (Fig. 2a), were analyzed as a location under influence of the PLC during the MECO. The Otway Basin contains a regionally thick sequence of shallowmarine Paleogene deposits (Gallagher et al., 1999; Gallagher and Holdgate, 2000). These deposits developed due to Paleocene-Eocene post-rift extension on the edge of the continental margin, causing subsidence of extensive troughs that served as depocenters of terrigenous sediment in deltaic and shallow marine environments (Krassay et al., 2004; Stacey et al., 2013; Frieling et al., 2018a). In southeast Australia, the middle Eocene to early Oligocene Nirranda Group unconformably overlies the early Eocene Dilwyn Formation (Fm) of the Wangerrip Group (Abele, 1994; Krassay et al., 2004; Tickell et al., 1993). This unconformity can be traced throughout southeast Australia (Holdgate et al., 2003). The overlying Wilson Bluff transgressive deposits have an age between 44 and $40 \mathrm{Ma}$ (Holdgate et al., 2003; McGowran et al., 2004). In the Portland Trough and Port Campbell Embayment of the Otway Basin, the basal part of the Nirranda Group consists mainly of the Burrungule Member and Sturgess Point Member. Outside of these main depocenters and on the ridges in between, the basal part of the Nirranda Group is represented by the Narrawaturk Fm. Planktonic foraminiferal biostratigraphy indicates a Bartonian age for the Sturgess Point Member (Abele, 1994; Gallagher and Holdgate, 2000).

The Latrobe- 1 borehole $\left(38.693009^{\circ} \mathrm{S}, 143.149995^{\circ} \mathrm{E}\right)$ was drilled in 1963-1964 near the Port Campbell Embayment, reaching a total depth of $620 \mathrm{~m}$. It spans Cretaceous to Eocene sediments, with initial biostratigraphic age con- 
straints (Archer, 1977; Taylor, 1964; Tickell et al., 1993) and well-log data (White, 1963) placing the middle Eocene Narrawaturk $\mathrm{Fm}$ at a depth of $60-76 \mathrm{~m}$ below surface (m b.s.), overlying the early Eocene Dilwyn Fm (76-289 mb.s.). The Dilwyn Fm in the Latrobe-1 core consists largely of light brown to dark brown sandstones with some contributions of mud- and siltstone, while the Narrawaturk Fm is a dark brown muddy sandstone (Frieling et al., 2018a). Based on the occurrence of the stratigraphic marker dinocysts Achilleodinium biformoides and Dracodinium rhomboideum, and in accordance with the regional dinocyst zonation (Bijl et al., 2013a), sediments around a depth of $67.35 \mathrm{~m}$ below surface (m b.s.) in the Narrawaturk Fm (Nirranda Group) of the Latrobe-1 borehole have an age near the MECO (Frieling et al., 2018a). Here, we target four samples from the Narrawaturk Fm in the Latrobe-1 core (interval $\sim 60-90 \mathrm{mb}$.s.) for palynology and organic geochemistry.

\subsection{Hampden Beach section (South Island, New Zealand)}

The Hampden Beach section at Hampden Beach, New Zealand (Fig. 2a) $\left(45.30^{\circ} \mathrm{S}, 170.83^{\circ} \mathrm{E}\right)$, was analyzed to identify influences of TC and/or EAC at southern New Zealand in the middle Eocene prior to the MECO (Hines et al., 2017). This $256.5 \mathrm{~m}$ thick section spans the Paleocene to late Eocene and has a well-resolved foraminiferal biostratigraphy (Morgans, 2009). Middle Eocene sediments of the Hampden Beach section consist of calcareous clay-rich siltstone to very fine sandstone. Benthic foraminiferal assemblages suggest a depositional environment near the shelfslope transition. An interval of $4 \mathrm{~m}$ was previously selected for high-resolution investigation (Burgess et al., 2008). This interval spans $70 \mathrm{kyr}$ around $41.7 \mathrm{Ma}$, based on biostratigraphy and orbital interpretation of lithological cycles. Seasurface temperature (SST) reconstructions based on $\mathrm{Mg} / \mathrm{Ca}$ and $\delta^{18} \mathrm{O}$ of excellently preserved foraminifera and TEX $\mathrm{T}_{86}$ indicate values of $23-25^{\circ} \mathrm{C}$ (Burgess et al., 2008), which is consistent with regional Eocene SST reconstructions (Hollis et al., 2012; Inglis et al., 2015). We have analyzed the same $4 \mathrm{~m}$ interval for dinocyst biogeography.

\section{Methods}

\subsection{Palynology}

\subsubsection{Processing and analysis}

A total of 43 samples from ODP Site 1170 (Hole 1170D), 8 samples from the Latrobe-1 core, and 39 samples from the Hampden Beach section were processed for palynology following standard procedures. A known amount of $L y$ copodium clavatum spores was added for quantification of the dinocyst content in specimens per gram. Sediment samples were crushed and oven dried $\left(60^{\circ} \mathrm{C}\right)$, followed by treatment with $30 \% \mathrm{HCl}$ and $\sim 40 \% \mathrm{HF}$ to dissolve carbonate and silicate minerals, respectively. After each acid step, samples were washed with water, centrifuged or settled for $24 \mathrm{~h}$, and decanted. The residue was sieved over nylon mesh sieves of 250 and $10 \mu \mathrm{m}$ (Site 1170) or $15 \mu \mathrm{m}$ (Otway Basin, Hampden Beach section) and subjected to an ultrasonic bath to break up agglutinated particles of the residue. A drop of the homogenized residue was mounted on a glass microscope slide with glycerine jelly and sealed. All slides are stored in the collection of the Laboratory of Palaeobotany and Palynology, Utrecht University. Palynomorphs were counted up to a minimum of 200 identified dinocysts for ODP Site 1170 , typically to the taxonomic level of genus or species. Because the dinocyst yield was relatively low for the other localities, palynomorphs were counted up to a minimum of 90 (Hampden Beach section) or 50 (Otway Basin) identified dinocysts. Terrestrial palynomorphs were counted in broad categories of gymnosperm pollen, angiosperm, pollen and spores for Site 1170 and the Hampden Beach section. As the Otway Basin samples yielded diverse and abundant sporomorph assemblages, a minimum of 300 sporomorphs was counted per sample. Dinocyst taxonomy as cited in Williams et al. (2017b) was generally followed, with the exception of the wetzelielloids. For this group, we follow the suggestion made in Bijl et al. (2016) to use the taxonomy of Fensome and Williams (2004) instead of Williams et al. (2015, 2017a). Sporomorph taxonomy follows Stover and Partridge (1973), Macphail et al. (1994), and Raine et al. (2011).

\subsubsection{Dinocyst biostratigraphy and paleogeographic affinity}

Regional dinocyst biostratigraphy for the middle Eocene is based on Bijl et al. (2013a) (ages presented in Table 2 of that work). Dinocyst-based environmental interpretation follows Sluijs et al. (2005), Sluijs and Brinkhuis (2009), and Frieling and Sluijs (2018). For biogeographic analysis, dinocyst taxa were binned into Antarctic endemics, cosmopolitan taxa, and mid-/low-latitude taxa (the Supplement). Shifts in relative abundance between these groups signal changes in surface-ocean currents. Surface-ocean currents deriving from the water surrounding Antarctica are dominated by Antarctic endemics, whereas low-latitude-derived currents such as the EAC and PLC transport more cosmopolitan and mid/low-latitude taxa. We primarily follow the biogeographical groupings of Bijl et al. (2011, 2013b), based on the occurrences and stratigraphic ranges of species at different latitudes. Cosmopolitan dinocysts are those taxa that have been recorded globally, at low (tropics), middle (subtropical and temperate), and high (polar) latitudes. The Antarctic endemic group consists of taxa endemic to either the Southern Ocean (including the Transantarctic Flora (TF); cf. Wrenn and Beckman, 1982) or both the Southern Ocean and northern high latitudes (bipolar taxa). To the mid/lowlatitude group, we add those taxa that are considered thermophilic (all wetzelielloids and goniodomids) based on re- 
cent empirical information on ecological affinities of Paleogene dinocysts (Frieling and Sluijs, 2018). We note that this addition only constitutes a minor change in biogeographic grouping for this study (the Supplement).

Taxa with unknown biogeographic affinities were excluded from biogeographical analysis. For instance, a large fraction of Deflandrea specimens that lost their outer bodies could not be identified to the species level. As some Deflandrea species are endemic to the SO, while others are cosmopolitan, we have excluded these specimens (and other taxa with unknown affinity) from biogeographic analysis. We note that a different choice was made for the published middle Eocene dinocyst assemblages from Site 1172, where the only Deflandrea species recorded was $D$. antarctica; consequently, Deflandrea inner bodies were counted as D. antarctica (Bijl et al., 2011). Endemic and cosmopolitan dinocysts during the MECO at Site 1170 and Site 1172 largely consist of two species belonging to the genus Enneadocysta, i.e., the cosmopolitan species Enneadocysta multicornuta and the Southern Ocean endemic Enneadocysta dictyostila. These species are morphologically similar, but differ by their tabulation patterns and the morphology of the distal ends of the processes (Fensome et al., 2006) (Fig. S1 in the Supplement). The species morphology has been crosschecked with the original Site 1172 material and dinocyst counts to validate consistency in species determination. The above biogeographical affinity of dinocysts, in particular the relative abundance of endemic vs. non-endemic dinocyst taxa, is used here to distinguish between the relative influence of the Antarcticderived TC and the lower-latitude-derived EAC and PLC.

\subsection{Organic geochemistry}

To quantify SST changes, 52 samples from ODP Hole 1170D and 1 sample from the Latrobe- 1 core were processed for $\mathrm{TEX}_{86}$ paleothermometry based on isoprenoid glycerol dibiphytanyl glycerol tetraether (GDGT) membrane lipids of marine archaea (Schouten et al., 2002). The GDGTs were extracted from freeze-dried, powdered samples $(\sim 8-10 \mathrm{~g}$ dry weight) with dichloromethane/methanol (DCM/MeOH) $(9: 1, v / v)$ using a Dionex accelerated solvent extractor (ASE) 350 , at a temperature of $100^{\circ} \mathrm{C}$ and a pressure of $7.6 \times 10^{6} \mathrm{~Pa}$. Lipid extracts were subsequently separated by $\mathrm{Al}_{2} \mathrm{O}_{3}$ column chromatography into four fractions, using hexane/dichloromethane (DCM) $(9: 1, v / v)$, ethyl acetate (100\%), DCM / MeOH (95: 5, v/v), and DCM / MeOH (1 : $1, v / v)$. For quantification purposes, $9.9 \mathrm{ng}$ of a $\mathrm{C}_{46}$ GDGT internal standard $(m / z$ 744) was added to the DCM $/ \mathrm{MeOH}$ $(95: 5, v / v)$ fraction after this. This fraction, containing the GDGTs, was subsequently dissolved in hexane/isopropanol (99:1, $v / v$ ) to a concentration of $\sim 3 \mathrm{mg} \mathrm{mL}^{-1}$, passed through a $0.45 \mu \mathrm{m}$ polytetrafluoroethylene (PTFE) filter, and analyzed using ultra-high-performance liquid chromatography mass spectrometry (UHPLC-MS) following Hopmans et al. (2016). We note that the published $\mathrm{TEX}_{86}$ records from
Site 1172 and the Hampden Beach section were generated using high-performance liquid chromatography mass spectrometry (HPLC-MS) after Schouten et al. (2007), but differences in TEX $_{86}$ values between the two methods have been shown to be negligible (Hopmans et al., 2016). Samples with very low concentrations (i.e., peak area $<3000 \mathrm{mV}$ and/or peak height $<3$ times background signal) of any GDGT included in $\mathrm{TEX}_{86}$ were excluded from analysis. Based on relative abundances of GDGTs, the TEX 86 and Branched versus Isoprenoid Tetraether (BIT) index values were calculated following Schouten et al. (2002) and Hopmans et al. (2004), respectively. The BIT index is used as an indicator for the contribution of terrestrially derived organic material to the marine realm, relative to the influence of marine production. High BIT index values indicate a primarily terrestrial origin of GDGTs and/or low marine production of GDGTs, whereas low BIT values indicate dominance of marine-produced GDGTs over a smaller contribution of terrestrial GDGTs. BIT index values $>0.3$ imply $\mathrm{TEX}_{86}$ might not correctly reflect SST due to an overprint by a terrestrialderived signal (Weijers et al., 2006). In addition, several other ratios were calculated to evaluate GDGT sourcing and thus the reliability of $\mathrm{TEX}_{86}$-based SST estimates. In short, the Methane Index (MI) (Zhang et al., 2011) and GDGT2/crenarchaeol (Weijers et al., 2011), GDGT-0/crenarchaeol (Blaga et al., 2009), and GDGT-2/GDGT-3 (Taylor et al., 2013) indices are calculated to investigate potential contributions by methanotrophic, methanogenic, and deep-dwelling GDGT producers to the GDGT pool in the sediments. The analytical precision for $\mathrm{TEX}_{86}$ is $\pm 0.3{ }^{\circ} \mathrm{C}$ based on longterm analysis of in-house standards. $\mathrm{TEX}_{86}$-to-SST calibrations include those based on mesocosm experiments and core-top datasets. We prefer the latter for paleoreconstructions, as these integrate ecological, water-column, and diagenetic effects that are not incorporated in mesocosm experiments. Since our measured $\mathrm{TEX}_{86}$ values are within the range of the modern core-top dataset $(\leq 0.73)$, no extrapolation of the modern $\mathrm{TEX}_{86}$-to-SST relationship is necessary, and differences between linearly and exponentially fitted calibrations are small (see, for example, extended data Fig. 2 in Cramwinckel et al., 2018). Here we calculate SST from TEX $_{86}$ values using both the exponential calibration of Kim et al. (2010) and the linear calibration of O'Brien et al. (2017) (the Supplement). Since the resulting values are highly similar, we present only the values from a single calibration, the $\mathrm{TEX}_{86}^{\mathrm{H}}$ calibration, in our figures. We note, however, that the interest of this study primarily lies in comparing geographic differences in SST and not absolute temperature values.

\subsection{Statistical analyses}

To assess the main patterns within the changing dinocyst assemblages at the studied sites, unconstrained ordination was applied on the proportional abundances. Both nonmetric multidimensional scaling (NMDS) and detrended correspon- 
dence analysis (DCA) were performed, using the R package Vegan (Oksanen et al., 2015). Whereas DCA assumes a unimodal species response to the environment, NMDS is a distance-based method that does not assume any relationship, which can be considered more neutral, because it introduces less assumptions (Prentice, 1977). For NMDS, the Bray-Curtis measure was used as an appropriate dissimilarity index for (paleo-)ecological community data (e.g., Faith et al., 1987), and recommendations by Clarke (1993) were followed to set the number (two or three) of dimensions used in the ordination. Unconstrained ordination was performed on the full dinocyst assemblages from Site 1170 and Hampden Beach (this study) as well as Site 1172 (Bijl et al., 2010, 2011, 2013a). Furthermore, unconstrained ordination was applied to the combined dinocyst assemblages of Site 1170, Site 1172, Otway Basin, and Hampden Beach. We note that caution should be taken when performing statistical analyses on microfossil assemblage counts of less than 150-200 palynomorphs (minimum 50 for Latrobe-1, minimum 90 for Hampden Beach), as diversity will likely be underrepresented. While this introduces biases into measures of diversity and variability of the assemblage, ordination-type analyses that establish the dominant patterns within the data should be more robust for low-count data.

To investigate whether dinocyst assemblage change at Site 1170 correlates with environmental change, constrained ordination using canonical correspondence analysis (CCA) was performed with the $\mathrm{R}$ package Vegan. We assess different sets of environmental proxy data, including SST (based on TEX ${ }_{86}$; this study), input of terrestrial material (BIT; this study), shipboard-generated clay contents from smear slide analysis, uranium contents, magnetic susceptibility, and color reflectance data (Mascle et al., 1996). Higherresolution environmental data were interpolated to the sampling resolution used here for palynology. As with DCA, CCA assumes a unimodal species response to the input environmental variables.

\section{Results}

\subsection{Site 1170}

\subsubsection{Palynology}

Middle Eocene palynomorphs at Site 1170 are generally well preserved and assemblages are dominated (> 95\%) by marine forms, mainly dinocysts. Terrestrial palynomorphs occur consistently but in low relative abundances $(<5 \%$ of palynomorphs). The presence of Impagidinium spp. in all samples indicates an open marine setting (Dale, 1996), suggesting that palynomorphs characteristic of inshore environments have been transported off shelf, possibly from the north. Absolute concentrations of dinocysts are extremely high, averaging $\sim 175000$ dinocysts per gram of dry sediment over the studied section, with maxima of over 400000 cysts per gram.
The dinocyst assemblages are generally of low diversity and consist of three dominant groups that typically comprise over $90 \%$ of the total assemblage. These groups are Enneadocysta dictyostila, Deflandrea spp., and spiny peridinioids sensu Sluijs et al. (2009). High abundances of Enneadocysta spp. and peridinioid dinocysts in combination with low diversity indicate a somewhat restricted, eutrophic assemblage with possible low-salinity influences (Sluijs et al., 2005). Endemic taxa dominate the record, typically accounting for more than half of the assemblage (Fig. 3). The most abundant endemic species is $E$. dictyostila, particularly from 570 to $690 \mathrm{mb}$.s.f. Endemic Vozzhennikovia apertura also has a high average relative abundance $(\sim 20 \%)$. Other rarer endemics include Arachnodinium antarcticum, Deflandrea antarctica, Enneadocysta brevistila, Octodinium askiniae, Spinidinium macmurdoense, S. schellenbergii, and Vozzhennikovia netrona. Cosmopolitan dinocyst species on average make up about $10 \%$ of the assemblage, consisting, among others, of Cerebrocysta spp., Cordosphaeridium spp., Enneadocysta multicornuta, Operculodinium centrocarpum, and Thalassiphora pelagica. Mid-/low-latitude taxa are rare. Selected taxa are illustrated in Fig. S1.

\subsubsection{Organic geochemistry and sea-surface temperatures}

Out of 52 samples from Hole 1170D, 5 were disregarded for TEX $_{86}$ analysis due to low GDGT concentrations, particularly in the lower part of the section. The remaining 47 samples have isoprenoid GDGT concentrations of on average of $18 \pm 10 \mathrm{ng}$ per gram of sediment. BIT index values (Hopmans et al., 2004) are consistently below 0.25 , indicating a dominant marine source of the isoprenoid GDGTs (Weijers et al., 2006). Furthermore, MI values (Zhang et al., 2011) and GDGT-2/Cren ratios (Weijers et al., 2011) are below 0.3 and 0.2 , respectively, indicating no substantial GDGT contributions by methanotrophic archaea. Finally, GDGT0/Cren ratios (Blaga et al., 2009) are never above 1.2, indicating normal marine conditions, without substantial contributions by methanogenic archaea. Based on the $\mathrm{TEX}_{86}^{\mathrm{H}}$ calibration, TEX 86 -derived SSTs are mostly between 20 and $28^{\circ} \mathrm{C}$, similar to time-equivalent temperatures at the East Tasman Plateau (Bijl et al., 2010) (Fig. 3). Maximum temperatures of $\sim 28^{\circ} \mathrm{C}$ are reached around $670 \mathrm{mb}$.s.f., and temperatures decline gradually towards the top of the studied section. Large temperature variability of several degrees between consecutive samples is recorded particularly in the interval from 600 to 550 mb.s.f. (Fig. 3).

\subsubsection{Biochronostratigraphic framework}

Some biostratigraphically informative dinocyst species are present. Selenopemphix spp. and Impagidinium parvireticulatum occur sparsely throughout the investigated samples from Site 1170, with their oldest occurrence at $\sim 766 \mathrm{mb}$.s.f. 

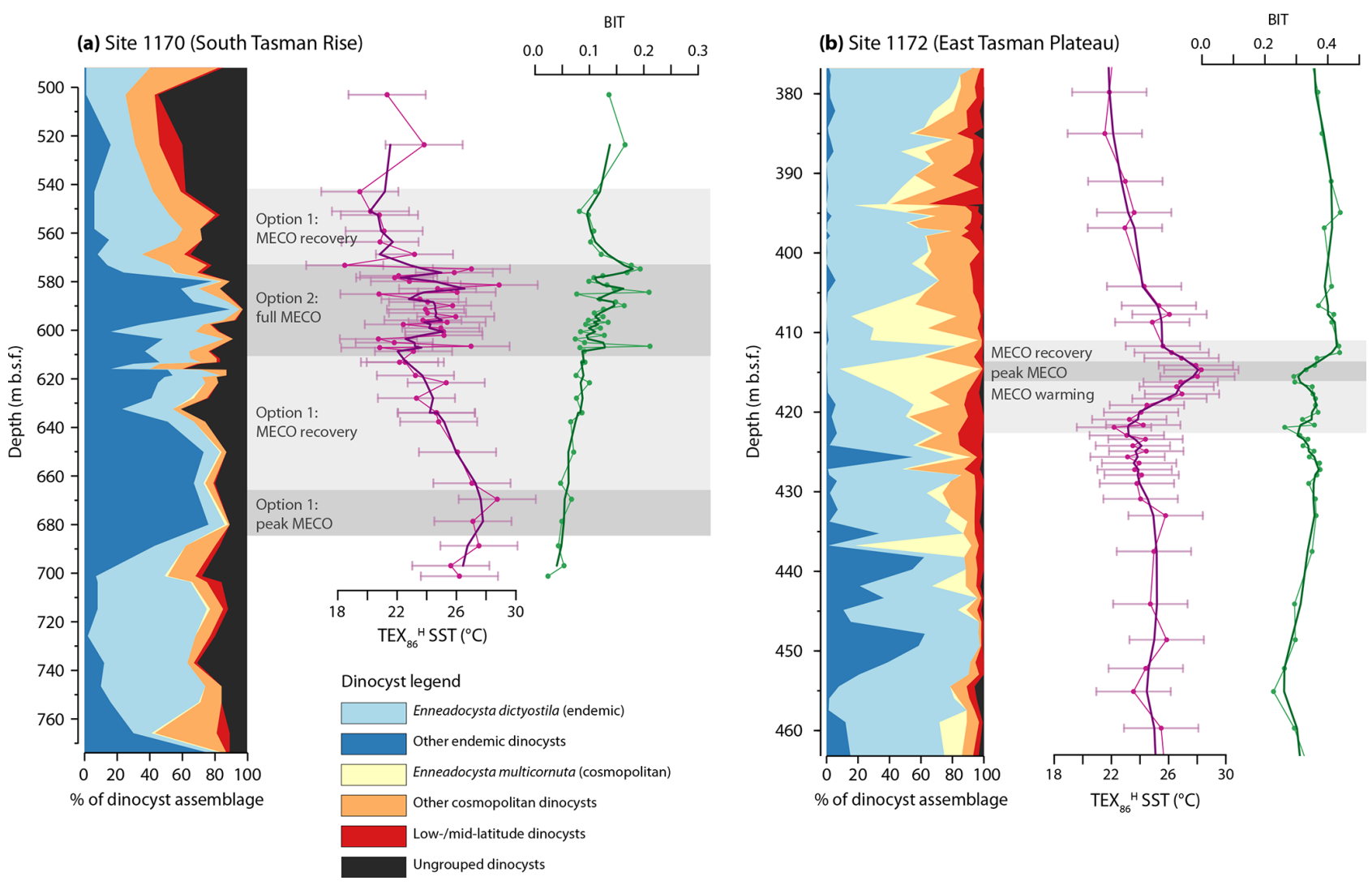

Figure 3. Dinocyst and temperature data from ODP Site 1170 and Site 1172. (a) Left: cumulative silhouette plot of relative abundances of dinocyst biogeographic groups at Site 1170. Especially for the younger part of the 1170 record, a high proportion of specimens of the genus Deflandrea could not be identified to the species level, causing the high abundance of the "others" group. Middle: TEX ${ }_{86}^{\mathrm{H}}{ }^{\text {-based }}{ }{ }^{\circ}{ }^{\circ}$ (in ${ }^{\circ} \mathrm{C}$ ) in pink, with a five-point moving average in purple. Error bars are combined calibration and analytical error $(1 \mathrm{SD})\left( \pm 2.6^{\circ} \mathrm{C}\right)$. Right: BIT in green, with a five-point moving average in dark green, plotted against depth in meters below seafloor on the vertical axis. Gray horizontal bars visualize the two different options for extent of the MECO, as presented in Sect. 4.1.3. (b) Same as (a) but for Site 1172. Data are from Bijl et al. (2010, 2011).

(second-to-lowermost sample). Their regional first occurrences are at 48.6 and 44.0 Ma (GTS2012), respectively (Bijl et al., 2013a). The presence of Impagidinium parvireticulatum thus constrains the studied sediments to an age younger than $44 \mathrm{Ma}$. The single occurrence of Lophocysta spp. at $569 \mathrm{mb}$.s.f. provides a narrow age range around the MECO for this part of the investigated core: from 41.39 to $39.66 \mathrm{Ma}$ (Bijl et al., 2013a). Additional age constraints from magnetostratigraphy are not possible, as inclination data suffered from a persistent, large overprint (Stickley et al., 2004a). The few available shipboard nannofossil datums do not add further constraints, but confirm that sediments of MECO age should lie within the studied interval (Stickley et al., 2004a). Based on the above constraints, we consider the recorded $\mathrm{TEX}_{86}$-based temperature maximum at $\sim 670 \mathrm{mb}$.s.f. to reflect the peak of the MECO and the subsequent surface-ocean cooling trend to represent the MECO recovery phase ("Option 1" in Fig. 3a). An alternative interpretation would be to consider the warming interval from $\sim 610$ to $\sim 580 \mathrm{mb}$.s.f. as MECO warming ("Option 2" in Fig. 3a), which would suggest peak-MECO temperatures at $\sim 580 \mathrm{mb}$.s.f. However, this would imply a pre-MECO peak in temperature at $\sim 670 \mathrm{mb}$ b.s.f. This would strongly conflict with temperature evolution across the middle Eocene and MECO as recorded at numerous sites across the global ocean, including nearby Site 1172 (e.g., Bijl et al., 2010; Boscolo-Galazzo et al., 2014; Cramwinckel et al., 2018). We therefore prefer the first interpretation, even though it implies (very) high sedimentation rates of tens of centimeters per thousand years. Such rates are consistent with the middle Eocene locality of Site 1170 in a depocenter on the northeast-southwest-rifting South Tasman Rise (Fig. 2b, c). While these constraints are valuable in delimiting our study interval to the MECO, stratigraphic correlation based on temperature records is precarious, and the lack of precise and consistent age-depth tiepoints impedes the construction of a solid age-depth model. We therefore present the data for Site 1170 in the depth domain. 


\subsection{Otway Basin}

\subsubsection{Marine palynology}

The palynomorph assemblages from the Latrobe-1 borehole consist predominantly of sporomorphs. Absolute concentrations of dinocysts are on the order of 100-1000 cysts per gram of dry sediment, while sporomorphs total 2000-5000 grains per gram of dry sediment. Sufficient dinocysts were encountered for counts of $\sim 50-100$ identified dinocysts to be undertaken. Other marine palynomorphs such as prasinophytes and acritarchs were rare. The Spiniferites complex is dominant (averaging $\sim 40 \%$ ), and Enneadocysta spp. (mostly consisting of E. multicornuta) are common (averaging $\sim 20 \%$ ). Other minor constituents include Cleistosphaeridium spp., Cordosphaeridium spp., Deflandrea spp., Elytrocysta spp., Hystrichosphaeridium spp., and Phthanoperidinium spp. Notably, the dinocyst assemblages do not yield Antarctic endemic taxa; instead, they are composed solely of cosmopolitan and low/midlatitude taxa. Combined, the marine palynology indicates a proximal marine setting.

\subsubsection{Terrestrial palynology}

The middle Eocene sporomorph assemblage from the Latrobe-1 borehole consists of abundant gymnosperm (30$50 \%)$ and angiosperm (30-50\%) pollen, with pteridophyte spores as a minor component of the assemblage (10$15 \%)$. Saccate pollen is mainly represented by Podocarpidites spp. (Podocarpus), Lygistepollenites (Dacrydium), and Phyllocladites spp. (Lagarostrobus); other gymnosperms are Araucariaceae (10-20\%), which consist mainly of Dilwynites spp. (Agathis/Wollemia) and, to a lesser extent, Araucariacites spp. (Araucaria). Angiosperm pollen is dominated by Myricipites spp. (Casuarinaceae; Gymnostoma), Nothofagidites (including Nothofagus subgenus (sg.) Brassospora) and Malvacipollis spp. (Austrobuxus/Dissilaria), with Proteacidites spp. and Rhoipites spp. as minor elements. Pteridophyte spores are mainly represented by Cyathidites spp. and Laevigatosporites spp. Furthermore, Cycadopites spp. (Cycadophyta), Arecipites spp. (Arecaeae), and Santalumidites spp. (Santalum) are also present but rare. Selected taxa are illustrated in Fig. S1. A stratigraphic log of the Latrobe-1 borehole and a pollen diagram are presented in Fig. S2.

\subsubsection{Organic geochemistry}

The analyzed sample from the Latrobe- 1 borehole contains predominantly terrestrial-derived branched GDGTs, resulting in a BIT index of 0.79 , making the sample unsuitable for $\mathrm{TEX}_{86}$ analysis.

\subsubsection{Stratigraphy}

Our new palynological data further constrain the position of the early-to-middle Eocene hiatus that was recognized in the Latrobe-1 borehole between 67.35 and $97.84 \mathrm{~m}$ b.s. (Frieling et al., 2018a) to a depth between 78.98 and $70.32 \mathrm{mb}$.s. The hiatus therefore likely corresponds to the transition between the Dilwyn Formation (Wangerrip Group) and the Narrawaturk Marl (Nirranda Group) at $\sim 70.5 \mathrm{~m}$ b.s. Dinocyst species with biostratigraphic utility in strata above the unconformity include Phthanoperidinium comatum (first occurrence (FO) $45.70 \pm 0.20 \mathrm{Ma}$ ) and Phthanoperidinium stockmansii (FO 57.20 $\pm 0.20 \mathrm{Ma}$ ), Achilleodinium biformoides (recorded in ODP Site 1171 South Pacific Dinocyst Zone (SPDZ) 13), and Dracodinium rhomboideum (Fig. S1c) (Bijl et al., 2013a). Occurrence of this last species is especially informative, as the stratigraphic range of Dracodinium rhomboideum in the South Pacific Dinocyst Zone of Bijl et al. (2013a) is very restricted. In fact, it was only present in one sample at Site 1172 , with an age of $40.00 \pm 0.10 \mathrm{Ma}$, within chron 18n.2n (denoted C18n.2n). This corresponds to peak MECO in the compilation of deep-sea stable-isotope records (Bohaty et al. 2009) as well as coinciding with peak MECO SSTs based on TEX 86 at Site 1172 . Notably, the range of D. rhomboideum in the North Atlantic Ocean (Eldrett et al., 2004) is similarly restricted to the MECO interval (from C18n.2n 0\% to C18n.1r 50\%, corresponding to $40.14-39.66 \mathrm{Ma}$ ), indicating this species to be a useful biostratigraphic marker for the MECO. The interval from 61.46 to $70.32 \mathrm{mb}$.s. in the Latrobe-1 borehole is therefore assigned to SPDZ13 (40.0-35.95 Ma) based on the regional dinocyst zonation of Bijl et al. (2013a). Moreover, the presence of Dracodinium rhomboideum in samples at 63.82 and $67.35 \mathrm{mb}$.s. indicates coverage of the MECO.

\subsection{Hampden Beach}

\section{Palynology}

Middle Eocene palynological assemblages at Hampden Beach are dominated by dinocysts (mean: $\sim 65 \%$ ), with abundant sporomorphs $(\sim 30 \%)$ and some acritarchs and prasinophytes. Sediments yield several thousand dinocysts per gram of dry sediment. The consistent presence of Impagidinium spp. (mean: $\sim 7 \%$ ) indicates an open-ocean setting. The dinocyst assemblages comprise predominantly cosmopolitan and low-/midlatitude taxa. Similar to the assemblages from the Latrobe-1 borehole, the outer neritic Spiniferites complex (срx.) is dominant (averaging $\sim 40 \%$ ). Other common cosmopolitan and low-/midlatitude taxa include Cordosphaeridium fibrospinosum, Dapsilidinium spp., Elytrocysta brevis, Hystrichokolpoma rigaudiae, Hystrichosphaeridium tubiferum, and Senegalinium spp. (together averaging $\sim 35 \%$ ). Antarctic endemic species occur sparsely (averaging $\sim 6 \%$ ) and consist of Deflandrea antarctica, Enneadocysta dictyostila, and Pyxidinopsis delicata. This 
dinocyst assemblage is in agreement with the age of ca. 41.7 Ma as previously assigned to this $4 \mathrm{~m}$ thick interval within the section (Burgess et al., 2008).

\section{Discussion}

\subsection{Surface-ocean circulation in the southwest Pacific Ocean during the MECO}

\subsubsection{Dinocyst constraints on MECO ocean circulation}

Our new dinocyst biogeographic data indicate that Antarctic endemic taxa dominated at the South Tasman Rise during the middle Eocene, while they did not occur in the Otway Basin within the Australo-Antarctic Gulf. Furthermore, a mixed assemblage with sparse endemics was found at Hampden Beach, New Zealand. This is generally consistent with previous interpretations of the surface-ocean circulation in and around the Tasmanian Gateway based on dinocyst biogeography (Bijl et al., 2011, 2013b) (Fig. 1b). By the middle Eocene, the Antarctic endemic dinocyst assemblage associated with the proto-ACC and TC had become firmly established in the SWP and on the Antarctic margin, while the northern bound of the AAG remained primarily influenced by the low-latitude-derived PLC (Bijl et al., 2011; Houben et al., 2019). Records from southern New Zealand yield a predominantly warm EAC signal (Hines et al., 2017), with a minor, yet constant, influx of Antarctic endemics indicating a limited TC influence (this study and Huber et al., 2004; Bijl et al., 2011).

Throughout the studied middle Eocene interval, dinocyst assemblages at Site 1170 are dominated by Antarctic endemic taxa. This implies that the Tasmanian Gateway was influenced by westward atmospheric and surface-oceanic circulation (i.e., the polar easterlies) around $40 \mathrm{Ma}$, with the polar front thus being located to the north of the gateway and the proto-ACC flowing westward through the Tasmanian Gateway (Fig. 1b). This is supported by the similar range of TEX ${ }_{86}$-derived SSTs of $20-28^{\circ} \mathrm{C}$ within (Site 1170) and east of (Site 1172) the Tasmanian Gateway (Fig. 3). In terms of paleolatitude reconstructions, placing Site 1170 within the Tasmanian Gateway south of $60^{\circ} \mathrm{S}$ at this time is within the uncertainty limits of current generation mantle (e.g., Matthews et al., 2016) and paleomagnetic reference frames (e.g., Torsvik et al., 2012). Notably, however, the shift in dominance from endemic to cosmopolitan dinocysts at the peak of MECO warmth on the East Tasman Plateau (Site 1172) (Bijl et al., 2010) has no equivalent on the South Tasman Rise (Site 1170) (Fig. 3). The dominant species at Site 1172 during peak MECO is cosmopolitan Enneadocysta multicornuta, while at the same time endemic Enneadocysta dictyostila is dominant at Site 1170 . While belonging to the same dinocyst genus and thus being morphologically closely related, these species have very different biogeographic affinities (e.g., Bijl et al. 2011). As both species oc- cur at both sites, and similar SSTs are reached during MECO, a purely paleoecological explanation for this disparity seems unlikely. Therefore, the difference between the dinocyst response at the East Tasman Plateau and South Tasman Rise requires a change in surface-ocean current configuration and dinocyst transport.

Given the dinocyst biogeographic patterns that are in place prior to the MECO (Bijl et al., 2011), three different surfaceocean currents might have brought dominant cosmopolitan dinocysts to Site 1172 during peak MECO: (1) flow from the southeast (with the Tasman Current), (2) flow from the north (as a southward extension of the East Australian Current), or (3) flow from the west (through the Tasmanian Gateway) (options depicted in Fig. 1c).

In scenario 1, a warmer TC could have resulted in a higher abundance of non-endemic species, including E. multicornuta that was able to dominate the assemblage under peak MECO warmth. However, in this scenario it seems likely that the TC would have supplied the same dinocyst assemblages to waters overlying Site 1170 at the STR - where we do not find them. In scenario 2, a southward extension of the EAC could have sustained cosmopolitan assemblages at Site 1172. An increased southward reach of the relatively warm EAC has been suggested before as a mechanism to warm the SWP throughout the hot early Eocene (Hines et al., 2017; Hollis et al., 2012). Model simulations for the modern system indicate that a wind-driven strengthening and further southward extent of the EAC are expected under conditions of enhanced global warmth, as part of intensification of the southern midlatitude circulation (Cai et al., 2005). Similarly, SST anomaly reconstructions over the peak interglacial Marine Isotope Stage $5 \mathrm{e}(\sim 125 \mathrm{ka})$ indicate intensification of the EAC to offshore Tasmania (Cortese et al., 2013). Possibly a similar atmospheric and oceanographic response to global warming occurred during MECO. General circulation model simulations have not yielded an EAC that reaches this far south during the Eocene (Lunt et al., 2012, 2020). However, simulations using a range of plausible geographies and bathymetries with higher resolution might show different small-scale circulation patterns in this sensitive region; therefore, we cannot discard this hypothesis at present. Although the Eocene EAC was likely located too far north to extend it all the way to Site 1172, we cannot, for example, rule out the possibility of an eddy-diffused influence of the EAC towards the ETP. In scenario 3, throughflow from the AAG into the SWP could have brought cosmopolitan assemblages to the ETP and not to the STR if flow went through Bass Strait and/or the northern portion of the Tasmanian Gateway. The uncertainty in paleolatitude in principle allows for weak, continuous eastward flow (or discontinuous eddy transport) under influence of the westerlies through the northern part of the TG. Although the Bass Strait, or Bass Basin, to the north of Tasmania might have been too restricted at its eastern end for throughflow, this remains poorly constrained (Cande and Stock, 2004). 


\subsubsection{Comparison to simulated ocean-circulation patterns}

At present, none of the above scenarios can be excluded given the available proxy data, geographical and bathymetrical constraints, and simulations. Climate-model simulations of various complexities can provide insights into the ocean circulation patterns that are possible under specific boundary conditions; the latter of which include, for example, geography, bathymetry, and radiative forcing. Complex general circulation models show multimodel consistency in simulating broad-scale gyral circulation in the southern Pacific and southern Atlantic/Indian sectors of the Eocene Southern Ocean (Lunt et al., 2012). However, the available simulations do not allow us to conclude on which of the above scenarios was the most likely for the Tasman region due to three primary reasons that we briefly discuss in the following.

The first is limitations in model resolution. In available climate-model simulations for the Eocene, mesoscale eddies are parameterized and not resolved, which affects the details of surface-ocean circulation, especially in regions of high eddy activity such as the (modern) Southern Ocean (Rintoul, 2018). Nooteboom et al. (in review) demonstrate the crucial role that eddy-diffusivity plays in realistically simulating ocean flow in models, particularly in assessing ocean flow from sedimentary microplankton assemblages. Eddy flow is notably important at oceanic fronts and also western boundary currents such as the EAC (Kirtman et al., 2012). Although low-resolution models adequately simulate general supra-regional ocean flow, the lack of proper eddy parameterization complicates using these models for the detailed purpose of assessing the above scenarios, particularly given the uncertainties in boundary conditions.

Secondly, there are large uncertainties regarding important details of regional (middle Eocene) geographic, bathymetric, and paleolatitudinal boundary conditions, as well as the timing and consequences of progressive changes therein (e.g., Hollis et al., 2012). These include the geometry of the TG conduit (both Tasmania-Antarctica and TasmaniaAustralia), the bathymetry of relative bathymetric highs such as the STR and Lord Howe Rise, sea level, and the regional shape of the coastlines around the Tasman Gateway, all of which might have a large impact on the resulting ocean flow (e.g., Olbers and Eden, 2003; Olbers et al., 2007, for the modern ACC). Although the available model simulations use best estimates on geography and bathymetry, the uncertainties remain large as a full sensitivity study is of course not feasible. This causes large uncertainty in both the plausibility of PLC eastward flow as well as the possibility for southward extent of the EAC. The impact of paleolatitude uncertainty becomes particularly evident when comparing moving hotspot reference frames with paleomagnetic reference frames (van Hinsbergen et al., 2015). Although the difference between these two models and the uncertainties within both are only a few degrees latitude, this may cause large dif- ferences in ocean-current direction through the TG, which is located close to the boundary between the Antarctic easterlies and midlatitude westerlies (Baatsen et al., 2016; Hines et al., 2017). Although the sensitivity of the TG to paleolatitude has been recognized conceptually (e.g., Scher et al., 2015), the oceanographic consequences of these varying paleolatitudinal models have not been simulated and compared in detail. Of relevance, for the above scenarios 2 and 3, are recent middle-to-late Eocene model simulations using CESM 1.0.5 (Baatsen et al., 2020) - with the Seton et al. (2012) paleogeography and the paleomagnetic reference frame from Torsvik et al. (2012) (described in Baatsen et al., 2016) simulating Southern Ocean frontal systems that were located much further south than under modern conditions, facilitating both southward EAC and eastward PLC flow.

The third reason considers the implications of the persistent regional mismatch between proxy- and model-based SST reconstructions on the interpretation of model simulations. While the match between multiproxy-based and model-simulated global mean temperature is improving for the (early) Eocene, the regional mismatch in SST in the SWP has remained large (Lunt et al., 2012, 2020), indicating gaps in our understanding of how heat was distributed regionally. Around New Zealand and south of Australia, modelbased SSTs are $5-10^{\circ} \mathrm{C}$ cooler than proxy estimates in simulations that show reasonable data-model consistency elsewhere. This results in much stronger local SST gradients in the model simulations than apparent in SST reconstructions. These generally lower SSTs for the SWP in model simulations will tend to increase the simulated strength and locus of deep-water formation in the South Pacific, affecting horizontal ocean flow as well through the pull from deep-water formation. This implies that underestimation of simulated absolute SSTs in the Eocene SWP possibly overestimates the simulated TG throughflow and, in turn, regional ocean current structure. Although proxy data are consistent with southern Pacific deep-water formation (Hollis et al., 2012; Huck et al., 2017), it is unknown what the strength, exact locus (Antarctic shelf versus deep-sea), or precise seasonality of that deep-water formation was.

In summary, while at this point we cannot select one of our proposed scenarios, our data show the presence of dinocyst assemblages derived from a lower-latitude current east of the TG and an Antarctic-derived current in the central TG during the zenith of MECO warmth. We stress the importance of this issue given the proximity of the Tasmanian Gateway to the likely region of deep-water formation in the South Pacific and the possible interaction between gateway throughflow and deep-water formation in the Eocene. We propose to revisit this issue with future simulations using high-resolution eddy-permitting models and improved constraints on regional paleogeography and bathymetry. These would be necessary to assess which of these scenarios is realistic in response to higher global temperatures during the Eocene and peak MECO. 


\subsection{Drivers of dinocyst assemblage change in the Tasmanian Gateway}

Unconstrained ordination using a unimodal (DCA) or nonmetric (NMDS) model shows that the primary variability in the dinocyst assemblage at Site 1170 is governed by E. dictyostila and follows SST quite closely (Figs. 4a; S3), suggesting that the abundance of $E$. dictyostila responds to temperature. The first NMDS and DCA axes are virtually identical, with DCA1 accounting for $33 \%$ of the variance in the dataset. Both DCA2 (accounting for 17\%) and MDS2 contrast $D$. antarctica and $T$. pelagica at one end of the axis with Vozzhennikovia spp. at the other end. Ordination results of the MECO and the surrounding interval at Site 1172 are closely comparable with those of Site 1170 (Figs. 4b, S3). At Site 1172, the abundance of E. dictyostila also controls the first axis (DCA1 accounting for $42 \%$ of the variance), and the second axis (accounting for 17\%) places D. antarctica and T. pelagica vs. Vozzhennikovia spp. No clear patterns in biogeographic or coastal proximity grouping emerge from the ordination results of Site 1170 or Site 1172. However, unconstrained ordination of the combined dinocyst assemblages from Site 1170, Site 1172, the Otway Basin, and Hampden Beach results in a biogeographic separation on the first axis (DCA1 accounting for $77 \%$ of the variance, DCA2 accounting for $38 \%$ ) (Fig. 5). DCA1 and MDS1 separate the Site 1170 and Site 1172 assemblages from the Otway Basin and Hampden Beach assemblages, as these axes separate endemic (and some cosmopolitan) taxa on the left $v s$. mid-/lowlatitude (and some cosmopolitan) taxa on the right. The second axis further separates Site 1170 from Site 1172.

The role of temperature in determining assemblage variability at Site 1170 is further supported by constrained ordination (CCA), in which the first axis has high explanatory power ( $\sim 67 \%$ of the total accounted variance by the environmental variables) and has $\mathrm{TEX}_{86}$ as the dominant component (Fig. 4c; environmental variables as time series in Fig. S4). Therefore, although no peak of low-latitude species characterizes the MECO at Site 1170, the ordination analyses suggest that the dinocyst assemblage as a whole, and in particular $E$. dictyostila, responded to temperature change during MECO.

Taken together, these results confirm previous evidence that once a surface-oceanography-tracking plankton community has become established, relative abundance changes within the community correspond closely with changes in SST (Bijl et al., 2011). In the modern ocean, phytoplankton distribution patterns are driven by the interplay of passive transport by surface currents and temperature selection (Thomas et al., 2012; Hellweger et al., 2016). A similar dual selection mechanism seems to have affected the middle Eocene dinocyst assemblages in the region. Regional surface-ocean circulation determined which assemblage was established and where. This spatial pattern (Fig. 5) could change over tectonic timescales as paleogeography changed (Bijl et al., 2011). Dominance shifts and variability within these assemblages were then driven by superimposed surface-ocean changes (such as in temperature), which typically occur on shorter timescales.

\subsection{Massive middle Eocene dinocyst productivity on the South Tasman Rise}

At the South Tasman Rise, MECO sediments are not only characterized by rapid sedimentation rates (on the order of tens of centimeters per thousand years according to our age models; compare Sect. 4.1.3) but also by high concentrations of dinocysts (Fig. 6). High sedimentation rates are readily explained by the location of Site 1170 as a middle Eocene depocenter affected by rifting between Australia and Antarctica as well as associated faulting of the STR (Exon et al., 2004). However, the extraordinarily high dinocyst concentrations are more difficult to explain. They are 100-1000 times higher than in the studied strata from the Otway Basin and Hampden Beach. They also stand out when compared to other time intervals and settings where high dinocyst concentrations are expected and found. Specifically, they are about an order of magnitude higher than those typically found in Mediterranean sapropels (e.g., Sangiorgi et al., 2006; van Helmond et al., 2015; Zwiep et al., 2018), Cretaceous Oceanic Anoxic Event 2 shelf sediments (van Helmond et al., 2014), and the Holocene Adélie drift underlying a highly productive polynya system (Hartman et al., 2018).

The high sedimentation rates and silty claystone facies make it unlikely that high dinocyst content was the result of sediment starvation and/or winnowing, respectively. Furthermore, such conditions would also have facilitated oxidation and degradation of organic-walled palynomorphs, while they are instead well preserved and abundant. Therefore, these high concentrations seem to represent extreme dinocyst productivity and/or preservation. Enhanced sediment accumulation rate by itself facilitates burial of organic matter, in particular through adsorption of organics to clay minerals (Berner, 2006; Hedges and Keil, 1995), so preservation could have played a role. However, total organic carbon (TOC) contents are not extremely high (mean: $\sim 1 \%$ over the studied interval), the sediment is well bioturbated, and there is no significant correlation between dinocysts per gram and shipboard TOC contents, uranium contents or magnetic susceptibility (Fig. S5), which suggests that preservation was not the driving factor leading to high dinocyst concentrations. Rather, surface-ocean productivity may have been elevated. The relatively low diversity of the dinocyst assemblages in combination with the high dominance of a single taxon (Enneadocysta dictyostila in the MECO interval) suggests a generally eutrophic setting that could have been characterized by seasonal plankton blooms. Notably, in several records from the Paleocene-Eocene Thermal Maximum (Harding et al., 2011; Sluijs et al., 2011; Frieling et al., 2018b), and a record from Oceanic Anoxic Event 2 at Bass 

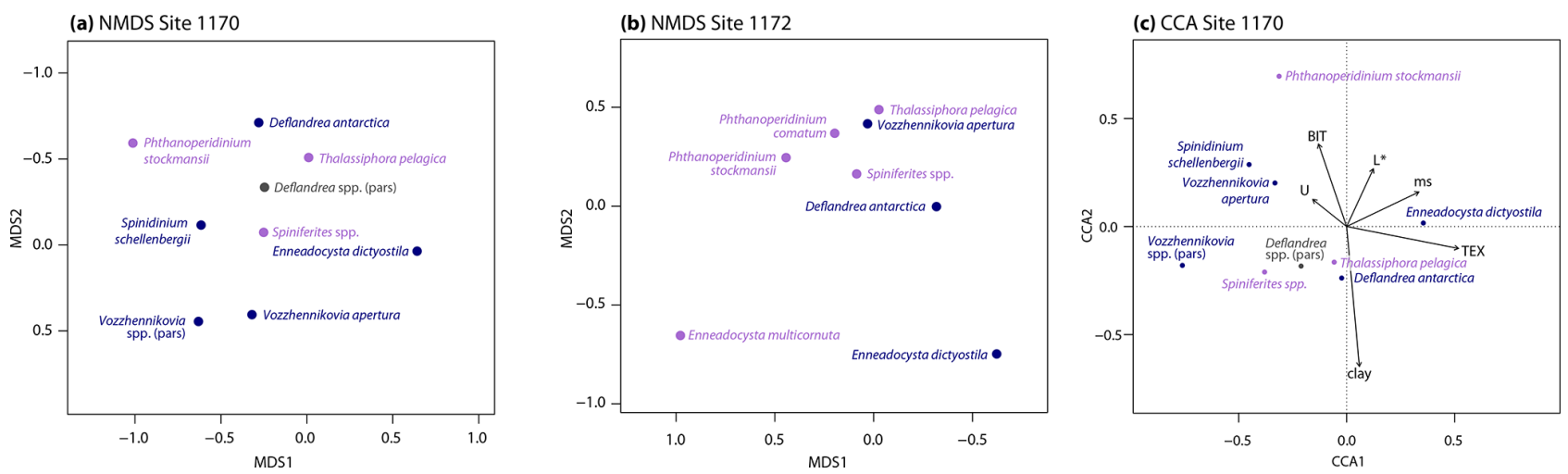

Figure 4. Ordination results. (a) Nonmetric multidimensional scaling ordination diagram for the dinocyst assemblage data of Site 1170. Species scores as circles and color-coded by biogeographic affinity (purple, cosmopolitan; blue, endemic; gray, not assigned). (b) Nonmetric multidimensional scaling ordination diagram for the dinocyst assemblage data of Site 1172. Species color coding as in (a). (c) Canonical correspondence analysis ordination diagram for the dinocyst assemblage data of Site 1170. Species color coding as in panel (a). Abbreviations are as follows: BIT, BIT index; clay, clay fraction (\%); L*, CIELAB lightness variable; ms, magnetic susceptibility; TEX, TEX 86 ; $\mathrm{U}_{\text {, uranium }}$ content. Total percentage of inertia in species data explained by environmental variables is $34 \%$. For visual clarity, only the most abundant taxa (taxa that occur in $>10 \%$ of the samples, have a mean relative abundance $>1 \%$, and have a maximum relative abundance of $>5 \%$ ) are shown in all three panels. Ordination plots showing all taxa are provided as Fig. S3.

River (van Helmond et al., 2014), highest concentrations of dinocysts reach 10000-100000 cysts per gram of sediment, and they also correspond to low diversity or high dominance assemblages suggestive of dinoflagellate blooms. Dinocysts deriving from heterotrophic dinoflagellates are present at Site 1170 but only in low abundances (the Supplement). This indicates that primary production of dinoflagellate prey such as diatoms (Jeong, 1999) was not necessarily high during the studied interval. Combined, the above results suggest that high surface-ocean dinoflagellate-based productivity combined with increased production of resting cysts was the most likely cause of rapid accumulation of dinocysts at Site 1170, with possible secondary roles for sediment transport and organic matter preservation. Indications of why conditions in the middle Eocene Tasmanian Gateway would have been extremely favorable for dinoflagellate or dinocyst production are, however, yet lacking.

\subsection{Southeast Australian vegetation during the MECO}

The middle Eocene sporomorph assemblages from the Latrobe-1 borehole are generally similar to those identified in previous studies (Macphail et al., 1994; Greenwood et al., 2003; Hill, 2017), but also include a small proportion of mesothermal-megathermal ("paratropical") components. Although the small number of analyzed samples prohibits a description of pre-, syn-, and post-MECO vegetation, the assemblages from the Latrobe-1 core reveal that this middle Eocene vegetation of coastal southeast Australia consisted of a mosaic of mesothermal rainforest flora. These forests were dominated by warm temperate angiosperms including Casuarinaceae (Gymnostoma), Austrobuxus/Dissilaria, and Proteaceae as shrubs and trees, with rare (paratropical) tree palms (Arecaceae) and cycads (Cycadophyta). Overstory elements included Nothofagus sg. Brassospora and gymnosperms of the Araucariaceae and Podocarpaceae (Podocarpus, Dacrydium, and Lagarostrobos). The low abundance of saccate Podocarpaceae pollen, i.e., pollen with a high transport capability that is often overrepresented in pollen assemblages, suggests that these taxa were not a major part of the coastal vegetation in the lower interval. Together with small trees and shrubs, ground ferns (Gleicheniaceae and Osmundaceae) and tree ferns (Cyatheaceae) occupied the understory in these rainforests. While the MECO marker dinocyst species Dracodinium rhomboideum was recorded in two of the four studied samples, further stratigraphic constraints are lacking. Future regional pollen studies focusing on the Nirranda Group might therefore elucidate whether the relatively thermophilous flora described here were restricted to the MECO interval or occurred within a broader interval of middle-to-late Eocene "background" conditions.

\subsection{Sea-level rise during the MECO}

Glacial eustacy might have played a minor role in middle Eocene sea-level changes (Dawber et al., 2011; Henehan et al., 2020), but direct, physical evidence for the presence of ice prior to the MECO has remained absent so far. Even with small glaciers present, accommodation space on the continental shelves (on timescales of $10^{6}-10^{7}$ years) was primarily determined by the interplay of steric components, sediment supply, and basin subsidence. In general, warm and wet early Eocene conditions are expected to have saturated passive continental shelves, resulting in relatively flat and shallow shelf platforms (Sømme et al., 2009). In 


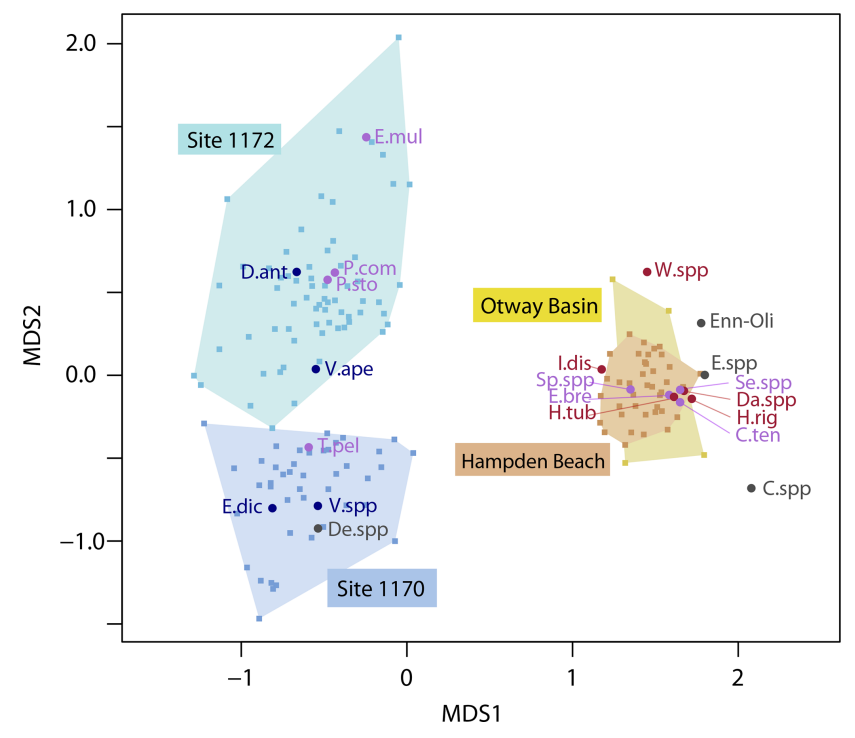

Figure 5. Nonmetric multidimensional scaling ordination diagram for the combined dinocyst assemblage data of Site 1170, Site 1172, Hampden Beach, and Otway Basin. Species scores as circles, colorcoded by biogeographic affinity (red, mid-/low-latitude; purple, cosmopolitan; blue, endemic; gray, not assigned). Samples scores as squares, color-coded by location (light blue, Site 1170; dark blue, Site 1172; orange, Hampden Beach; yellow, Otway Basin), with shading connecting same-location samples. Abbreviations are as follows: C.spp, Corrudinium spp. (pars); C.ten, Cribroperidinium tenuitabulatum; Da.spp, Dapsilidinium spp.; D.ant, Deflandrea antarctica; De.spp, Deflandrea spp.; E.bre, Elytrocysta brevis; E.dic, Enneadocysta dictyostila; E.mul, Enneadocysta multicornuta; Enn-Oli, Enneadocysta-Oligosphaeridium intermediate; E. spp, Enneadocysta spp. (pars); H.rig, Hystrichokolpoma rigaudiae; H.tub, Hystrichosphaeridium tubiferum; I.dis, Impagidinium dispertitum; P.com, Phthanoperidinium comatum; P.sto, Phthanoperidinium stockmansii; Se.spp, Senegalinium spp. (pars); Sp.spp, Spiniferites spp. (pars); T.pel, Thalassiphora pelagica; V.ape, Vozzhennikovia apertura; V.spp, Vozzhennikovia spp. (pars); W.spp, wetzelielloids. For visual clarity, only the most abundant taxa are shown.

the Otway Basin, sediments of middle Eocene age (basal Nirranda Group) overlie a large unconformity at the top of early Eocene sediments of the Wangerrip Group (e.g., Krassay et al., 2004). These middle Eocene sediments were deposited during the Wilson Bluff transgression, which is recognized throughout southeast Australia (Holdgate et al., 2003; McGowran et al., 2004) and has been linked to a major transgressive phase in the Indo-Pacific region (the Khirthar transgression) (Jauhri and Agarwal, 2001; McGowran et al., 2004). While there is seismostratigraphic evidence for regional tectonic rifting, normal faulting, and subsidence during the Paleocene and early Eocene in southeast Australia (Krassay et al., 2004; Close et al., 2009), it is unknown when subsidence terminated and renewed. Additionally, a progressive decrease in terrigenous sediment supply as the
Australian hinterland became arid throughout the Eocene might have affected accommodation space (Sauermilch et al., 2019). Whatever the relative contributions of these mechanisms, the hiatus between the Wangerrip Group and the Nirranda Group suggests no or negative accommodation space by the end of the early Eocene (51 Ma) or later. The renewed drowning of the continental shelf, as reflected in the Wilson Bluff transgression, seems unlikely to be related to slow and continuous basin subsidence. Instead, ocean warming during the MECO may have raised global average sea level by several meters by thermal expansion, while a warmer and wetter regional climate could have increased sediment supply. The resumption of sedimentation accumulation above the top Latrobe unconformity has been previously dated to between 44 and $40 \mathrm{Ma}$ (Holdgate et al., 2003; McGowran et al., 2004). Based on our new dinocyst-based age constraints, it is likely that the sediments overlying the Wangerrip Group are close to the MECO in age, suggestive of a causal link between the Wilson Bluff transgression and MECO warming. A similar timing of renewed sedimentation occurred in the Schöningen section in the North German Basin, where the transgressive, fully marine Annenberg Formation unconformably overlies the Lutetian coal-bearing Helmstedt Formation (Riegel et al., 2012). The Annenberg Formation has been assigned an age around the MECO (Gürs et al., 2002), possibly $\sim 41 \mathrm{Ma}$ (Brandes et al., 2012). Based on a compilation of New Jersey coastal plain sections, a highstand (sequence E8) is also interpreted at $\sim 41-40 \mathrm{Ma}$ (Browning et al., 2008).

Sea-level rise and warming during the MECO may have accommodated increased burial of biogenic carbonate on continental shelves, explaining a reduction in carbonate burial in the deep sea (Sluijs et al., 2013), along with a diminished silicate weathering feedback (van der Ploeg et al., 2018). However, it should be noted that the above inferences regarding global sea-level rise during the MECO are tentative. Although these transgressive surfaces all have an age around the MECO, current age control is not nearly sufficient to correlate them to $\mathrm{MECO}$ with certainty. A dating accuracy of $\leq 100000$ years would be required for these transgressive surfaces to indicate their relationship to MECO warming, which is presently not available. It is therefore crucial to improve these constraints in order to assess the potential influence of sea-level change on the carbon cycle during the MECO.

\section{Conclusions}

Comparison of plankton and sea-surface temperature patterns during the MECO above the South Tasman Rise indicates that dinocyst assemblages as a whole responded to surface-water warming. However, the acme in cosmopolitan taxa above the East Tasman Plateau at peak MECO is not mirrored at the STR. This implies transport by a warming Tasman Current, a southward extension of the EAC, or east- 

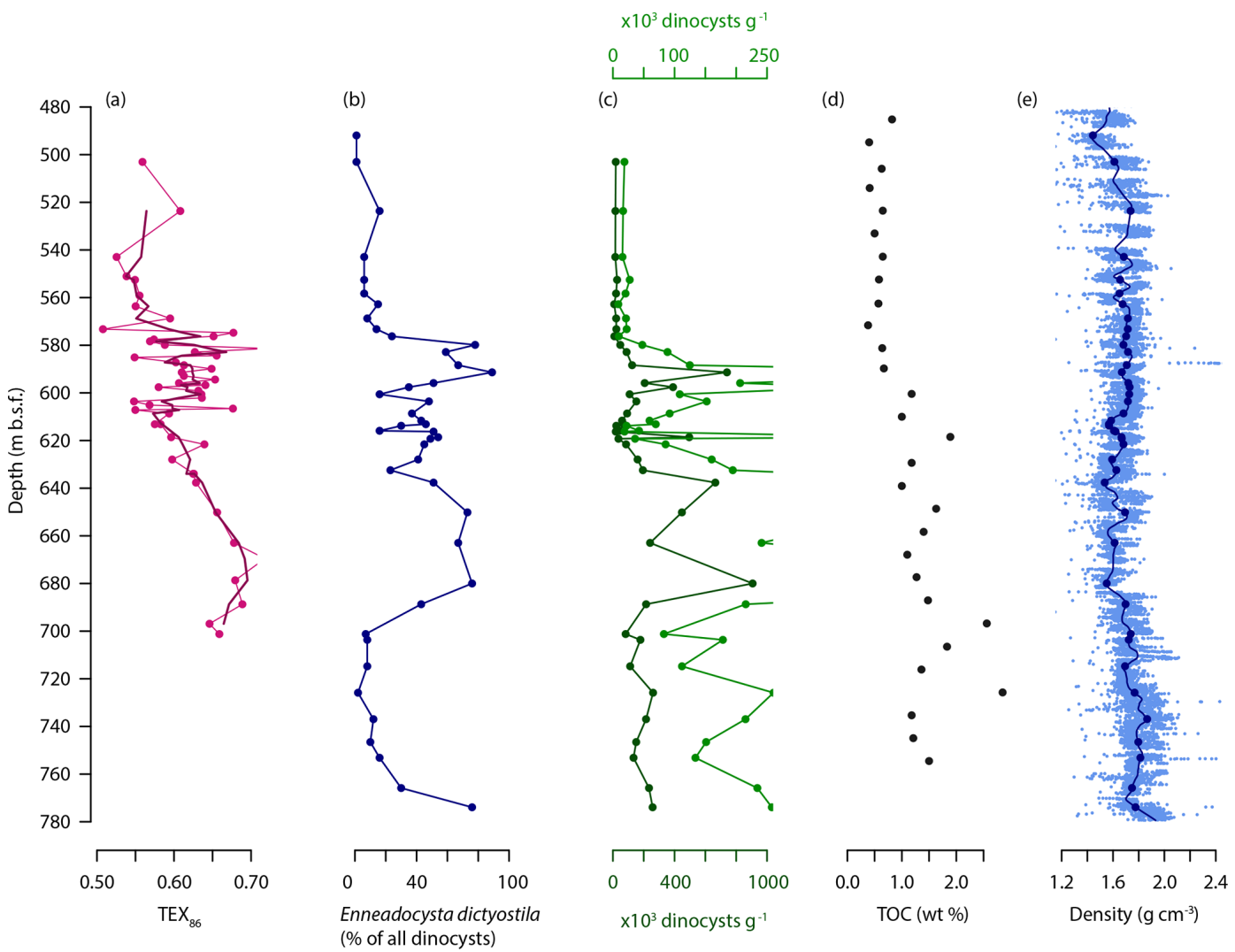

Figure 6. Selected proxy records over the MECO interval of Site 1170, plotted against depth in meters below sea level (mb.s.1.). (a) TEX 86 (pink dots and line), with three-point moving average (purple lines). (b) Relative abundance of Enneadocysta dictyostila (percentage of total dinocyst assemblage; dark blue dots and line). (c) Dinoflagellate cyst content (cysts per gram of dry sediment; two different scales shown for visual clarity in dark green and light green). (d) Total organic carbon (weight percentage; black dots) (from Exon et al., 2001). (e) Gamma ray attenuation (GRA) sediment density (in $\mathrm{g} \mathrm{cm}^{-3}$; light blue dots original data; dark blue line LOESS fit; dark blue dots interpolated LOESS fit to depth of dinocyst samples) (from Exon et al., 2001).

ward throughflow through the northern portion of the Tasmanian Gateway during the zenith of MECO warmth. While we cannot distinguish between these scenarios, this seems to illustrate that surface-ocean currents can respond to external climate forcing in these regions of the Southern Ocean. Terrestrial palynomorph assemblages indicate that a warm temperate rainforest with paratropical elements grew along the southeast Australian margin during the MECO. Finally, we suggest that the southeast Australian Wilson Bluff Transgression may be related to sea-level rise during the MECO, but improvement of the available age constraints is necessary to establish a possible causal link. Data availability. Data are available at
https://doi.org/10.17605/OSF.IO/TZM9K (Cramwinckel, 2020).

Supplement. The supplement related to this article is available online at: https://doi.org/10.5194/cp-16-1667-2020-supplement.
Author contributions. AS and PKB designed the research. MJC, LW, GJR, AS, and PKB generated and analyzed data from ODP Site 1170. MJC, EPH, SJG, JP, and PKB generated and analyzed data from the Latrobe-1 borehole. CEB and PKB generated and analyzed data from the Hampden section. MJC interpreted the GDGT data, together with FP, GJR, AS, and PKB; interpreted the palynological data, together with LW, EPH, JP, AS, and PKB; compiled the data; and wrote the paper with input from all authors.

Competing interests. The authors declare that they have no conflict of interest.

Acknowledgements. This research used samples and data provided by the International Ocean Discovery Program (IODP) and its predecessors. This research has been supported by the Dutch Ministry of Education, Culture and Science. We thank Natasja Welters, Jan van Tongeren, and Arnold van Dijk (Utrecht University Geo$\mathrm{Lab}$ ) for analytical support. We thank Guy Holdgate, Steven Bohaty, and Joost Frieling for fieldwork and sampling assistance. We thank the reviewers Severine Fauquette, Chris Hollis, and G. Raquel 
Guerstein for their constructive reviews and Yannick Donnadieu for thorough editing of the manuscript.

Financial support. This work was carried out under the program of the Netherlands Earth System Science Centre (NESSC), financially supported by the Dutch Ministry of Education, Culture and Science. Margot J. Cramwinckel and Appy Sluijs thank the Ammodo Foundation for funding unfettered research of laureate Appy Sluijs. This study was made possible by the Netherlands Organisation for Scientific Research (NWO) (grant no. 834.11.006), which enabled the purchase of the UHPLC-MS system used for GDGT analyses. Funding was provided by the Australian IODP office and the ARC Basins Genesis Hub (IH130200012) to Stephen J. Gallagher.

Review statement. This paper was edited by Yannick Donnadieu and reviewed by Chris Hollis, G. Raquel Guerstein, and Severine Fauquette.

\section{References}

Abele, C.: Early Eocene Burrungule Member (Wangerrip Group, Gambier Embayment) and middle Eocene Sturgess Point Member (Nirranda Group, Port Campbell Embayment) in the Otway Basin, southeastern Australia, Geological Survey of Victoria, Unpublished Report (1994/12), 1994.

Anagnostou, E., John, E. H., Edgar, K. M., Foster, G. L., Ridgwell, A., Inglis, G. N., Pancost, R. D., Lunt, D. J., and Pearson, P. N.: Changing atmospheric $\mathrm{CO}_{2}$ concentration was the primary driver of early Cenozoic climate, Nature, 533, 380-384, https://doi.org/10.1038/nature17423, 2016.

Archer, V.: Palynology of the Victorian Mines Department Latrobe 1 Bore, Otway Basin, Victoria, 1977.

Baatsen, M., van Hinsbergen, D. J. J., von der Heydt, A. S., Dijkstra, H. A., Sluijs, A., Abels, H. A., and Bijl, P. K.: Reconstructing geographical boundary conditions for palaeoclimate modelling during the Cenozoic, Clim. Past, 12, 1635-1644, https://doi.org/10.5194/cp-12-1635-2016, 2016.

Baatsen, M., von der Heydt, A. S., Huber, M., Kliphuis, M. A., Bijl, P. K., Sluijs, A., and Dijkstra, H. A.: The middle-to-late Eocene greenhouse climate, modelled using the CESM 1.0.5, Clim. Past Discuss., https://doi.org/10.5194/cp-2020-29, in review, 2020.

Berner, R. A.: Comment: Mesozoic Atmospheric Oxygen (Comment on "MAGic: A phanerozoic model for the geochemical cycling of major rock-forming components" by Rolf S. Arvidson, Fred T. Mackenzie and Michael Guidry, American Journal of Science, v. 306, p. 135-190.), Am. J. Sci., 306, 769-771, 2006.

Bijl, P. K., Schouten, S., Sluijs, A., Reichart, G.-J., Zachos, J. C., and Brinkhuis, H.: Early Palaeogene temperature evolution of the southwest Pacific Ocean, Nature, 461, 776-779, https://doi.org/10.1038/nature08399, 2009.

Bijl, P. K., Houben, A. J. P., Schouten, S., Bohaty, S. M., Sluijs, A., Reichart, G.-J., Damsté, J. S. S., and Brinkhuis, H.: Transient Middle Eocene Atmospheric $\mathrm{CO}_{2}$ and Temperature Variations, Science, 330, 819-821, https://doi.org/10.1126/science.1193654, 2010.
Bijl, P. K., Pross, J., Warnaar, J., Stickley, C. E., Huber, M., Guerstein, R., Houben, A. J. P., Sluijs, A., Visscher, H., and Brinkhuis, H.: Environmental forcings of Paleogene Southern Ocean dinoflagellate biogeography, Paleoceanography, 26, PA1202, https://doi.org/10.1029/2009PA001905, 2011.

Bijl, P. K., Sluijs, A., and Brinkhuis, H.: A magneto- and chemostratigraphically calibrated dinoflagellate cyst zonation of the early Palaeogene South Pacific Ocean, Earth-Sci. Rev., 124, 1-31, https://doi.org/10.1016/j.earscirev.2013.04.010, 2013a.

Bijl, P. K., Bendle, J. A. P., Bohaty, S. M., Pross, J., Schouten, S., Tauxe, L., Stickley, C. E., McKay, R. M., Röhl, U., Olney, M., Sluijs, A., Escutia, C., Brinkhuis, H., Klaus, A., Fehr, A., Williams, T., Carr, S. A., Dunbar, R. B., Gonzàlez, J. J., Hayden, T. G., Iwai, M., Jimenez-Espejo, F. J., Katsuki, K., Kong, G. S., Nakai, M., Passchier, S., Pekar, S. F., Riesselman, C., Sakai, T., Shrivastava, P. K., Sugisaki, S., Tuo, S., Flierdt, T. van de, Welsh, K., and Yamane, M.: Eocene cooling linked to early flow across the Tasmanian Gateway, Proc. Natl. Acad. Sci. USA, 110, 96459650, https://doi.org/10.1073/pnas.1220872110, 2013b.

Bijl, P. K., Brinkhuis, H., Egger, L. M., Eldrett, J. S., Frieling, J., Grothe, A., Houben, A. J. P., Pross, J., Śliwińska, K. K., and Sluijs, A.: Comment on "Wetzeliella and its allies - the "hole" story: a taxonomic revision of the Paleogene dinoflagellate subfamily Wetzelielloideae" by Williams et al. (2015), Palynology, 6122, 1-7, https://doi.org/10.1080/01916122.2016.1235056, 2016.

Blaga, C. I., Reichart, G.-J., Heiri, O., and Damsté, J. S. S.: Tetraether membrane lipid distributions in water-column particulate matter and sediments: a study of 47 European lakes along a north-south transect, J. Paleolimnol., 41, 523-540, https://doi.org/10.1007/s10933-008-9242-2, 2009.

Bohaty, S. M. and Zachos, J. C.: Significant Southern Ocean warming event in the late middle Eocene, Geology, 31, 1017-1020, https://doi.org/10.1130/G19800.1, 2003.

Bohaty, S. M., Zachos, J. C., Florindo, F., and Delaney, M. L.: Coupled greenhouse warming and deep-sea acidification in the middle Eocene, Paleoceanography, 24, PA2207, https://doi.org/10.1029/2008PA001676, 2009.

Boscolo-Galazzo, F., Thomas, E., Pagani, M., Warren, C., Luciani, V., and Giusberti, L.: The middle Eocene climatic optimum (MECO): A multiproxy record of paleoceanographic changes in the southeast Atlantic (ODP Site 1263, Walvis Ridge), Paleoceanography, 29, 2014PA002670, https://doi.org/10.1002/2014PA002670, 2014.

Boscolo-Galazzo, F., Thomas, E., and Giusberti, L.: Benthic foraminiferal response to the Middle Eocene Climatic Optimum (MECO) in the South-Eastern Atlantic (ODP Site 1263), Palaeogeogr. Palaeoclimatol. Palaeoecol., 417, 432-444, https://doi.org/10.1016/j.palaeo.2014.10.004, 2015.

Brandes, C., Pollok, L., Schmidt, C., Wilde, V., and Winsemann, J.: Basin modelling of a lignite-bearing salt rim syncline: insights into rim syncline evolution and salt diapirism in NW Germany, Basin Res., 24, 699-716, https://doi.org/10.1111/j.13652117.2012.00544.x, 2012.

Browning, J. V., Miller, K. G., Sugarman, P. J., Kominz, M. A., McLaughlin, P. P., Kulpecz, A. A., and Feigenson, M. D.: $100 \mathrm{Myr}$ record of sequences, sedimentary facies and sea level change from Ocean Drilling Program onshore core- 
holes, US Mid-Atlantic coastal plain, Basin Res., 20, 227-248, https://doi.org/10.1111/j.1365-2117.2008.00360.x, 2008.

Burgess, C. E., Pearson, P. N., Lear, C. H., Morgans, H. E. G., Handley, L., Pancost, R. D., and Schouten, S.: Middle Eocene climate cyclicity in the southern Pacific: Implications for global ice volume, Geology, 36, 651-654, https://doi.org/10.1130/G24762A.1, 2008.

Cai, W., Shi, G., Cowan, T., Bi, D., and Ribbe, J.: The response of the Southern Annular Mode, the East Australian Current, and the southern mid-latitude ocean circulation to global warming, Geophys. Res. Lett., 32, L23706, https://doi.org/10.1029/2005GL024701, 2005.

Cande, S. C. and Stock, J. M.: Cenozoic Reconstructions of the Australia-New Zealand-South Pacific Sector of Antarctica, in The Cenozoic Southern Ocean: tectonics, sedimentation, and climate change between Australia and Antarctica, edited by N. F. Exon, J. P. Kennett, and M. J. Malone, pp. 5-17, American Geophysical Union, Washington, DC., available at: http://resolver. caltech.edu/CaltechAUTHORS:20140425-125510082 (last access: 8 August 2018), 2004.

Carpenter, R. J., Jordan, G. J., Macphail, M. K., and Hill, R. S.: Near-tropical Early Eocene terrestrial temperatures at the Australo-Antarctic margin, western Tasmania, Geology, 40, 267270, https://doi.org/10.1130/G32584.1, 2012.

Clarke, K. R.: Non-parametric multivariate analyses of changes in community structure, Austral. J. Ecol., 18, 117-143, https://doi.org/10.1111/j.1442-9993.1993.tb00438.x, 1993.

Close, D. I., Watts, A. B., and Stagg, H. M. J.: A marine geophysical study of the Wilkes Land rifted continental margin, Antarctica, Geophys. J. Int., 177, 430-450, https://doi.org/10.1111/j.1365246X.2008.04066.x, 2009.

Contreras, L., Pross, J., Bijl, P. K., Koutsodendris, A., Raine, J. I., van de Schootbrugge, B., and Brinkhuis, H.: Early to Middle Eocene vegetation dynamics at the Wilkes Land Margin (Antarctica), Rev. Palaeobot. Palynol., 197, 119-142, https://doi.org/10.1016/j.revpalbo.2013.05.009, 2013.

Contreras, L., Pross, J., Bijl, P. K., O’Hara, R. B., Raine, J. I., Sluijs, A., and Brinkhuis, H.: Southern high-latitude terrestrial climate change during the Palaeocene-Eocene derived from a marine pollen record (ODP Site 1172, East Tasman Plateau), Clim. Past, 10, 1401-1420, https://doi.org/10.5194/cp-10-1401-2014, 2014.

Cortese, G., Dunbar, G. B., Carter, L., Scott, G., Bostock, H., Bowen, M., Crundwell, M., Hayward, B. W., Howard, W., Martínez, J. I., Moy, A., Neil, H., Sabaa, A., and Sturm, A.: Southwest Pacific Ocean response to a warmer world: Insights from Marine Isotope Stage 5e, Paleoceanography, 28, 585-598, https://doi.org/10.1002/palo.20052, 2013.

Cramwinckel, M. J.: Surface-circulation change in the southwest Pacific Ocean across the Middle Eocene Climatic Optimum: inferences from dinoflagellate cysts and biomarker paleothermometry, OSF, https://doi.org/10.17605/OSF.IO/TZM9K, 2020.

Cramwinckel, M. J., Huber, M., Kocken, I. J., Agnini, C., Bijl, P. K., Bohaty, S. M., Frieling, J., Goldner, A., Hilgen, F. J., Kip, E. L., Peterse, F., Ploeg, R. van der, Röhl, U., Schouten, S., and Sluijs, A.: Synchronous tropical and polar temperature evolution in the Eocene, Nature, 559, 382-386, https://doi.org/10.1038/s41586018-0272-2, 2018.

Cramwinckel, M. J., van der Ploeg, R., Bijl, P. K., Peterse, F., Bohaty, S. M., Röhl, U., Schouten, S., Middelburg, J.
J., and Sluijs, A.: Harmful algae and export production collapse in the equatorial Atlantic during the zenith of Middle Eocene Climatic Optimum warmth, Geology, 47, 247-250, https://doi.org/10.1130/G45614.1, 2019.

Dale, B.: Dinoflagellate cyst ecology: modeling and geological applications, in: Palynology: Principles and Applications, edited by: Jansonius, J., McGregor, D. C., AASP Foundation, 12491275, 1996.

Dawber, C. F., Tripati, A. K., Gale, A. S., MacNiocaill, C., and Hesselbo, S. P.: Glacioeustasy during the middle Eocene? Insights from the stratigraphy of the Hampshire Basin, UK, Palaeogeogr. Palaeoclimatol. Palaeoecol., 300, 84-100, https://doi.org/10.1016/j.palaeo.2010.12.012, 2011.

Eldrett, J. S., Harding, I. C., Firth, J. V., and Roberts, A. P.: Magnetostratigraphic calibration of Eocene-Oligocene dinoflagellate cyst biostratigraphy from the Norwegian-Greenland Sea, Mar. Geol., 204, 91-127, https://doi.org/10.1016/S00253227(03)00357-8, 2004.

Exon, N. F., Kennett, J. P., and Malone, M. J.: Proceedings of the Ocean Drilling Program Initial Reports, Ocean Drilling Program, College Station, TX, 2001.

Exon, N. F., Kennett, J. P., and Malone, M. J.: The Cenozoic Southern Ocean: Tectonics, Sedimentation, and Climate Change Between Australia and Antarctica, Wiley, 2004.

Faith, D. P., Minchin, P. R., and Belbin, L.: Compositional dissimilarity as a robust measure of ecological distance, Vegetatio, 69, 57-68, https://doi.org/10.1007/BF00038687, 1987.

Fensome, R. A. and Williams, G. L.: The Lentin and Williams Index of Fossil Dinoflagellates, American Association of Stratigraphic Palinologists Foundation, 2004.

Fensome, R. A., Guerstein, G. R., and Williams, G. L.: New insights on the Paleogene dinoflagellate cyst genera Enneadocysta and Licracysta gen. nov. based on material from offshore eastern Canada and southern Argentina, Micropaleontology, 52, 385410, https://doi.org/10.2113/gsmicropal.52.5.385, 2006.

Frieling, J. and Sluijs, A.: Towards quantitative environmental reconstructions from ancient non-analogue microfossil assemblages: Ecological preferences of Paleocene - Eocene dinoflagellates, Earth-Sci. Rev., 185, 956-973, https://doi.org/10.1016/j.earscirev.2018.08.014, 2018.

Frieling, J., Huurdeman, E. P., Rem, C. C. M., Donders, T. H., Pross, J., Bohaty, S. M., Holdgate, G. R., Gallagher, S. J., McGowran, B., and Bijl, P. K.: Identification of the Paleocene-Eocene boundary in coastal strata in the Otway Basin, Victoria, Australia, J. Micropalaeontol., 37, 317-339, https://doi.org/10.5194/jm-37317-2018, 2018a.

Frieling, J., Reichart, G.-J., Middelburg, J. J., Röhl, U., Westerhold, T., Bohaty, S. M., and Sluijs, A.: Tropical Atlantic climate and ecosystem regime shifts during the Paleocene-Eocene Thermal Maximum, Clim. Past, 14, 39-55, https://doi.org/10.5194/cp-1439-2018, 2018b.

Gallagher, S. J. and Holdgate, G.: The palaeogeographic and palaeoenvironmental evolution of a Palaeogene mixed carbonate-siliciclastic cool-water succession in the Otway Basin, Southeast Australia, Palaeogeogr. Palaeoclimatol. Palaeoecol., 156, 19-50, https://doi.org/10.1016/S0031-0182(99)00130-3, 2000.

Gallagher, S. J., Jonasson, K., and Holdgate, G.: Foraminiferal biofacies and palaeoenvironmental evolution of an Oligo- 
Miocene cool-water carbonate succession in the Otway Basin, southeast Australia, J. Micropalaeontol., 18, 143-168, https://doi.org/10.1144/jm.18.2.143, 1999.

Greenwood, D. R., Moss, P. T., Rowett, A. I., Vadala, A. J., and Keefe, R. L.: Plant communities and climate change in southeastern Australia during the early Paleogene, in Causes and consequences of globally warm climates in the early Paleogene, edited by: Wing, S. L., Gingerich, P. D., Schmitz, B., Thomas, E., Geological Society of America, 365-380, 2003.

Gürs, K., Lietzow, A., and Ritzkowski, S.: Das Tertiär Nordwestdeutschlands in der Stratigraphischen Tabelle von Deutschland 2002, available at: http://www.stratigraphie.de/std2002/ download/STD2002_large.pdf (last access: 19 August 2020), 2002.

Harding, I. C., Charles, A. J., Marshall, J. E. A., Pälike, H., Roberts, A. P., Wilson, P. A., Jarvis, E., Thorne, R., Morris, E., Moremon, R., Pearce, R. B., and Akbari, S.: Sea-level and salinity fluctuations during the Paleocene-Eocene thermal maximum in Arctic Spitsbergen, Earth Planet. Sci. Lett., 303, 97-107, https://doi.org/10.1016/j.eps1.2010.12.043, 2011.

Hartman, J. D., Bijl, P. K., and Sangiorgi, F.: A review of the ecological affinities of marine organic microfossils from a Holocene record offshore of Adélie Land (East Antarctica), J. Micropalaeontol., 37, 445-497, https://doi.org/10.5194/jm-37445-2018, 2018.

Harwood, D. M.: Cenozoic diatom biogeography in the southern high latitudes: Inferred biogeographical barriers and progressive endemism, in: Geological Evolution of Antarctica: Proceedings of the Fifth International Symposium on Antarctic Earth Sciences, edited by: Thompson, M. R. A., et al., Cambridge University Press, Cambridge, UK, pp. 667-673, 1991.

Hedges, J. I. and Keil, R. G.: Sedimentary organic matter preservation: an assessment and speculative synthesis, Mar. Chem., 49, 81-115, https://doi.org/10.1016/0304-4203(95)00008-F, 1995.

Hellweger, F. L., Sebille, E. van, Calfee, B. C., Chandler, J. W., Zinser, E. R., Swan, B. K., and Fredrick, N. D.: The Role of Ocean Currents in the Temperature Selection of Plankton: Insights from an Individual-Based Model, PLOS ONE, 11, e0167010, https://doi.org/10.1371/journal.pone.0167010, 2016.

Henehan, M. J., Edgar, K. M., Foster, G. L., Penman, D. E., Hull, P. M., Greenop, R., Anagnostou, E., and Pearson, P. N.: Revisiting the Middle Eocene Climatic Optimum "Carbon Cycle Conundrum" with new estimates of atmospheric $p \mathrm{CO}_{2}$ from boron isotopes, Paleoceanogr. Paleoclimatol., 35, e2019PA003713, https://doi.org/10.1029/2019PA003713, 2020.

Hill, P. J. and Exon, N. F.: Tectonics and Basin Development of the Offshore Tasmanian Area Incorporating Results from Deep Ocean Drilling, in: The Cenozoic Southern Ocean: tectonics, sedimentation, and climate change between Australia and Antarctica, edited by: Exon, N. F., Kennett, J. P., Malone, M. J., American Geophysical Union, Washington, DC, pp. 19-42, 2004.

Hill, P. J. and Moore, A. M. G.: Geological Framework of the South Tasman Rise and East Tasman Plateau, Geoscience Australia, 2001.

Hill, R. S.: History of the Australian Vegetation: Cretaceous to Recent, University of Adelaide Press, Adelaide, 2017.

Hines, B. R., Hollis, C. J., Atkins, C. B., Baker, J. A., Morgans, H. E. G. and Strong, P. C.: Reduction of oceanic temperature gradients in the early Eocene Southwest Pacific Ocean, Palaeogeogr. Palaeoclimatol. Palaeoecol., 475, 41-54, https://doi.org/10.1016/j.palaeo.2017.02.037, 2017.

Holdgate, G. R., Rodriquez, C., Johnstone, E. M., Wallace, M. W., and Gallagher, S. J.: The Gippsland Basin Top Latrobe unconformity, and its expression in other SE Australian basins, APPEA J., 43, 149-173, https://doi.org/10.1071/aj02007, 2003.

Hollis, C. J., Handley, L., Crouch, E. M., Morgans, H. E. G., Baker, J. A., Creech, J., Collins, K. S., Gibbs, S. J., Huber, M., Schouten, S., Zachos, J. C., and Pancost, R. D.: Tropical sea temperatures in the high-latitude South Pacific during the Eocene, Geology, 37, 99-102, https://doi.org/10.1130/G25200A.1, 2009.

Hollis, C. J., Taylor, K. W. R., Handley, L., Pancost, R. D., Huber, M., Creech, J. B., Hines, B. R., Crouch, E. M., Morgans, H. E. G., Crampton, J. S., Gibbs, S., Pearson, P. N., and Zachos, J. C.: Early Paleogene temperature history of the Southwest Pacific Ocean: Reconciling proxies and models, Earth Planet. Sci. Lett., 349-350, 53-66, https://doi.org/10.1016/j.epsl.2012.06.024, 2012.

Hopmans, E. C., Weijers, J. W. H., Schefuß, E., Herfort, L., Sinninghe Damsté, J. S., and Schouten, S.: A novel proxy for terrestrial organic matter in sediments based on branched and isoprenoid tetraether lipids, Earth Planet. Sci. Lett., 224, 107-116, https://doi.org/10.1016/j.epsl.2004.05.012, 2004.

Hopmans, E. C., Schouten, S., and Sinninghe Damsté, J. S.: The effect of improved chromatography on GDGT-based palaeoproxies, Organ. Geochem., 93, 1-6, https://doi.org/10.1016/j.orggeochem.2015.12.006, 2016.

Houben, A. J. P., Bijl, P. K., Sluijs, A., Schouten, S., and Brinkhuis, H.: Late Eocene Southern Ocean Cooling and Invigoration of Circulation Preconditioned Antarctica for FullScale Glaciation, Geochem. Geophy. Geosy., 20, 2214-2234, https://doi.org/10.1029/2019GC008182, 2019.

Huber, M. and Caballero, R.: The early Eocene equable climate problem revisited, Clim. Past, 7, 603-633, https://doi.org/10.5194/cp-7-603-2011, 2011.

Huber, M., Brinkhuis, H., Stickley, C. E., Döös, K., Sluijs, A., Warnaar, J., Schellenberg, S. A., and Williams, G. L.: Eocene circulation of the Southern Ocean: Was Antarctica kept warm by subtropical waters?, Paleoceanography, 19, PA4026, https://doi.org/10.1029/2004PA001014, 2004.

Huck, C. E., Flierdt, T. van de, Bohaty, S. M., and Hammond, S. J.: Antarctic climate, Southern Ocean circulation patterns, and deep water formation during the Eocene, Paleoceanography, 32, 674-691, https://doi.org/10.1002/2017PA003135, 2017.

Inglis, G. N., Farnsworth, A., Lunt, D., Foster, G. L., Hollis, C. J., Pagani, M., Jardine, P. E., Pearson, P. N., Markwick, P., Galsworthy, A. M. J., Raynham, L., Taylor, Kyle. W. R., and Pancost, R. D.: Descent toward the Icehouse: Eocene sea surface cooling inferred from GDGT distributions, Paleoceanography, 30, 2014PA002723, https://doi.org/10.1002/2014PA002723, 2015.

Jauhri, A. K. and Agarwal, K. K.: Early Palaeogene in the south Shillong Plateau, NE India: local biostratigraphic signals of global tectonic and oceanic changes, Palaeogeogr. Palaeoclimatol. Palaeoecol., 168, 187-203, https://doi.org/10.1016/S00310182(00)00255-8, 2001.

Jeong, H. J.: The Ecological Roles of Heterotrophic Dinoflagellates in Marine Planktonic Community1, J. Eu- 
karyot. Microbiol., 46, 390-396, https://doi.org/10.1111/j.15507408.1999.tb04618.x, 1999.

Kennett, J. P., Houtz, R. E., Andrews, P. B., Edwards, A. R., Gostin, V. A., Hajos, M., Hampton, M. A., Jenkins, D. G., Margolis, S. V., Ovenshine, A. T. and Perch-Nielsen, K.: Development of the Circum-Antarctic Current, Science, 186, 144-147, https://doi.org/10.1126/science.186.4159.144, 1974.

Kim, J.-H., van der Meer, J., Schouten, S., Helmke, P., Willmott, V., Sangiorgi, F., Koç, N., Hopmans, E. C., and Sinninghe Damsté, J. S.: New indices and calibrations derived from the distribution of crenarchaeal isoprenoid tetraether lipids: Implications for past sea surface temperature reconstructions, Geochim. Cosmochim. Ac., 74, 4639-4654, https://doi.org/10.1016/j.gca.2010.05.027, 2010.

Kirtman, B. P., Bitz, C., Bryan, F., Collins, W., Dennis, J., Hearn, N., Kinter, J. L., Loft, R., Rousset, C., Siqueira, L., Stan, C., Tomas, R., and Vertenstein, M.: Impact of ocean model resolution on CCSM climate simulations, Clim. Dynam., 39, 13031328, https://doi.org/10.1007/s00382-012-1500-3, 2012.

Krassay, A. A., Cathro, D. L., and Ryan, D. J.: A Regional Tectonostratigraphic Framework for the Otway Basin, in Eastern Australasian Basins Symposium II, edited by: Boult, P. J., Johns, D. R., and Lang, S. C., pp. 97-116, Adelaide, available at: http://archives.datapages.com/data/ petroleum-exploration-society-of-australia/conferences/002/ 002001/pdfs/97.html (last access: 24 September 2018), 2004.

Lagabrielle, Y., Goddéris, Y., Donnadieu, Y., Malavieille, J., and Suarez, M.: The tectonic history of Drake Passage and its possible impacts on global climate, Earth Planet. Sci. Lett., 279, 197211, https://doi.org/10.1016/j.eps1.2008.12.037, 2009.

Lazarus, D. B., Hollis, C. J., and Apel, M.: Patterns of Opal and Radiolarian change in the Antarctic Mid-Paleogene: Clues to the Origin of the Southern Ocean, Micropaleontology, 54, 41-48, 2008.

Lunt, D. J., Dunkley Jones, T., Heinemann, M., Huber, M., LeGrande, A., Winguth, A., Loptson, C., Marotzke, J., Roberts, C. D., Tindall, J., Valdes, P., and Winguth, C.: A modeldata comparison for a multi-model ensemble of early Eocene atmosphere-ocean simulations: EoMIP, Clim. Past, 8, 17171736, https://doi.org/10.5194/cp-8-1717-2012, 2012.

Lunt, D. J., Bragg, F., Chan, W.-L., Hutchinson, D. K., Ladant, J.B., Niezgodzki, I., Steinig, S., Zhang, Z., Zhu, J., Abe-Ouchi, A., de Boer, A. M., Coxall, H. K., Donnadieu, Y., Knorr, G., Langebroek, P. M., Lohmann, G., Poulsen, C. J., Sepulchre, P., Tierney, J., Valdes, P. J., Dunkley Jones, T., Hollis, C. J., Huber, M., and Otto-Bliesner, B. L.: DeepMIP: Model intercomparison of early Eocene climatic optimum (EECO) large-scale climate features and comparison with proxy data, Clim. Past Discuss., https://doi.org/10.5194/cp-2019-149, in review, 2020.

Macphail, M. K., Alley, N. F., Truswell, E. M., and Sluiter, I. R. K.: Early Tertiary vegetation: Evidence from spores and pollen, in History of the Australian vegetation: Cretaceous to Recent, edited by: Hill, R. S., University of Adelaide Press, Adelaide, pp. 189-261, 1994.

Mascle, J., Lohmann, G. P., Clift, P. D., and Shipboard Scientific Party: Proceedings of the Ocean Drilling Program Initial Reports, College Station, TX (Ocean Drilling Program), 1996.

Matthews, K. J., Maloney, K. T., Zahirovic, S., Williams, S. E., Seton, M. and Müller, R. D.: Global plate boundary evolution and kinematics since the late Paleozoic, Global Planet. Change, 146, 226-250, https://doi.org/10.1016/j.gloplacha.2016.10.002, 2016.

McGowran, B., Holdgate, G. R., Li, Q., and Gallagher, S. J.: Cenozoic stratigraphic succession in southeastern Australia, Austral. J. Earth Sciences, 51, 459-496, https://doi.org/10.1111/j.14000952.2004.01078.x, 2004.

Morgans, H. E. G.: Late Paleocene to middle Eocene foraminiferal biostratigraphy of the Hampden Beach section, eastern South Island, New Zealand, New Zealand J. Geol. Geophys., 52, 273320, https://doi.org/10.1080/00288306.2009.9518460, 2009.

Nelson, C. S. and Cooke, P. J.: History of oceanic front development in the New Zealand sector of the Southern Ocean during the Cenozoic - a synthesis, New Zealand J. Geol. Geophys., 44, 535-553, https://doi.org/10.1080/00288306.2001.9514954, 2001.

Nooteboom, P. D., Delandmeter, P., van Sebille, E., Bijl, P. K., Dijkstra, H. A., and von der Heydt, A. S.: Resolution-dependent variations of sinking Lagrangian particles in general circulation models, arXiv:2004.07099 [physics], available at: http://arxiv. org/abs/2004.07099 (last access: 3 May 2020), 2020.

O’Brien, C. L., Robinson, S. A., Pancost, R. D., Sinninghe Damsté, J. S., Schouten, S., Lunt, D. J., Alsenz, H., Bornemann, A., Bottini, C., Brassell, S. C., Farnsworth, A., Forster, A., Huber, B. T., Inglis, G. N., Jenkyns, H. C., Linnert, C., Littler, K., Markwick, P., McAnena, A., Mutterlose, J., Naafs, B. D. A., Püttmann, W., Sluijs, A., van Helmond, N. A. G. M., Vellekoop, J., Wagner, T., and Wrobel, N. E.: Cretaceous sea-surface temperature evolution: Constraints from TEX86 and planktonic foraminiferal oxygen isotopes, Earth-Sci. Rev., 172, 224-247, https://doi.org/10.1016/j.earscirev.2017.07.012, 2017.

Oksanen, J., Guillaume Blanchet, F., Kindt, R., Legendre, P., Minchin, P. R., O'Hara, R. B., Simpson, G. L., Solymos, P., Stevens, M. H. H., and Wagner, H.: vegan: Community Ecology Package. R package version 2.3-0, available at: http://CRAN. R-project.org/package=vegan (last access: 18 August 2020), 2015.

Olbers, D. and Eden, C.: A Simplified General Circulation Model for a Baroclinic Ocean with Topography. Part I: Theory, Waves, and Wind-Driven Circulations, J. Phys. Oceanogr., 33, 2719-2737, https://doi.org/10.1175/15200485(2003)033<2719:ASGCMF>2.0.CO;2, 2003.

Olbers, D., Lettmann, K., and Timmermann, R.: Six circumpolar currents-on the forcing of the Antarctic Circumpolar Current by wind and mixing, Ocean Dynam., 57, 12-31, https://doi.org/10.1007/s10236-006-0087-9, 2007.

Pancost, R. D., Taylor, K. W. R., Inglis, G. N., Kennedy, E. M., Handley, L., Hollis, C. J., Crouch, E. M., Pross, J., Huber, M., Schouten, S., Pearson, P. N., Morgans, H. E. G., and Raine, J. I.: Early Paleogene evolution of terrestrial climate in the SW Pacific, Southern New Zealand, Geochem. Geophy. Geosy., 14, 5413-5429, https://doi.org/10.1002/2013GC004935, 2013.

Pascher, K. M., Hollis, C. J., Bohaty, S. M., Cortese, G., McKay, R. M., Seebeck, H., Suzuki, N., and Chiba, K.: Expansion and diversification of high-latitude radiolarian assemblages in the late Eocene linked to a cooling event in the southwest Pacific, Clim. Past, 11, 1599-1620, https://doi.org/10.5194/cp-11-1599-2015, 2015.

Prentice, I. C.: Non-Metric Ordination Methods in Ecology, J. Ecol., 65, 85-94, https://doi.org/10.2307/2259064, 1977. 
Pross, J., Contreras, L., Bijl, P. K., Greenwood, D. R., Bohaty, S. M., Schouten, S., Bendle, J. A., Röhl, U., Tauxe, L., Raine, J. I., Huck, C. E., van de Flierdt, T., Jamieson, S. S. R., Stickley, C. E., van de Schootbrugge, B., Escutia, C., Brinkhuis, H., and Scientists, I. O. D. P. E. 318: Persistent near-tropical warmth on the Antarctic continent during the early Eocene epoch, Nature, 488, 73-77, https://doi.org/10.1038/nature11300, 2012.

Raine, J. I., Mildenhall, D. C., and Kennedy, E. M.: New Zealand fossil spores and pollen: an illustrated catalogue. 4th edition, GNS Science miscellaneous series no. 4, available at: http://data. gns.cri.nz/sporepollen/index.htm (last access: 18 August 2020), 2011.

Riegel, W., Wilde, V., and Lenz, O. K.: The early Eocene of Schöningen (N-Germany) - an interim report, Austral. J. Earth Sci., 105, 88-109, 2012.

Rintoul, S. R.: The global influence of localized dynamics in the Southern Ocean, Nature, 558, 209-218, https://doi.org/10.1038/s41586-018-0182-3, 2018.

Röhl, U., Brinkhuis, H., Stickley, C. E., Fuller, M., Schellenberg, S. A., Wefer, G., and Williams, G. L.: Sea Level and Astronomically Induced Environmental Changes in Middle and Late Eocene Sediments from the East Tasman Plateau, in: The Cenozoic Southern Ocean: Tectonics, Sedimentation, and Climate Change Between Australia and Antarctica, edited by: Exon, N. F., Kennett, J. P., Lone, M. J., pp. 127-151, American Geophysical Union, available at: http://onlinelibrary.wiley.com/doi/10.1029/ 151GM09/summary (last access: 17 November 2015), 2004.

Sangiorgi, F., Dinelli, E., Maffioli, P., Capotondi, L., Giunta, S., Morigi, C., Principato, M. S., Negri, A., Emeis, K.C., and Corselli, C.: Geochemical and micropaleontological characterisation of a Mediterranean sapropel S5: A case study from core BAN89GC09 (south of Crete), Palaeogeogr. Palaeoclimatol. Palaeoecol., 235, 192-207, https://doi.org/10.1016/j.palaeo.2005.09.029, 2006.

Sauermilch, I., Whittaker, J. M., Bijl, P. K., Totterdell, J. M., and Jokat, W.: Tectonic, Oceanographic, and Climatic Controls on the Cretaceous-Cenozoic Sedimentary Record of the AustralianAntarctic Basin, J. Geophys. Res.-Sol. Ea., 124, 7699-7724, https://doi.org/10.1029/2018JB016683, 2019.

Scher, H. D. and Martin, E. E.: Circulation in the Southern Ocean during the Paleogene inferred from neodymium isotopes, Earth Planet. Sci. Lett., 228, 391-405, https://doi.org/10.1016/j.epsl.2004.10.016, 2004.

Scher, H. D., Whittaker, J. M., Williams, S. E., Latimer, J. C., Kordesch, W. E. C., and Delaney, M. L.: Onset of Antarctic Circumpolar Current 30 million years ago as Tasmanian Gateway aligned with westerlies, Nature, 523, 580-583, https://doi.org/10.1038/nature14598, 2015.

Schouten, S., Hopmans, E. C., Schefuß, E., and Sinninghe Damsté, J. S.: Distributional variations in marine crenarchaeotal membrane lipids: a new tool for reconstructing ancient sea water temperatures?, Earth Planet. Sci. Lett., 204, 265-274, https://doi.org/10.1016/S0012-821X(02)00979-2, 2002.

Schouten, S., Huguet, C., Hopmans, E. C., Kienhuis, M. V. M., and Sinninghe Damsté, J. S.: Analytical Methodology for TEX86 Paleothermometry by High-Performance Liquid Chromatography/Atmospheric Pressure Chemical Ionization-Mass Spectrometry, Anal. Chem., 79, 2940-2944, https://doi.org/10.1021/ac062339v, 2007.
Seton, M., Müller, R. D., Zahirovic, S., Gaina, C., Torsvik, T., Shephard, G., Talsma, A., Gurnis, M., Turner, M., Maus, S., and Chandler, M.: Global continental and ocean basin reconstructions since $200 \mathrm{Ma}$, Earth-Sci. Rev., 113, 212-270, https://doi.org/10.1016/j.earscirev.2012.03.002, 2012.

Sijp, W. P., England, M. H., and Huber, M.: Effect of the deepening of the Tasman Gateway on the global ocean, Paleoceanography, 26, PA4207, https://doi.org/10.1029/2011PA002143, 2011.

Sijp, W. P., von der Heydt, A. S., Dijkstra, H. A., Flögel, S., Douglas, P. M. J., and Bijl, P. K.: The role of ocean gateways on cooling climate on long time scales, Global Planet. Change, 119, 1-22, https://doi.org/10.1016/j.gloplacha.2014.04.004, 2014.

Sijp, W. P., von der Heydt, A. S., and Bijl, P. K.: Model simulations of early westward flow across the Tasman Gateway during the early Eocene, Clim. Past, 12, 807-817, https://doi.org/10.5194/cp-12-807-2016, 2016.

Sluijs, A. and Brinkhuis, H.: A dynamic climate and ecosystem state during the Paleocene-Eocene Thermal Maximum: inferences from dinoflagellate cyst assemblages on the New Jersey Shelf, Biogeosciences, 6, 1755-1781, https://doi.org/10.5194/bg-61755-2009, 2009.

Sluijs, A., Brinkhuis, H., Stickley, C. E., Warnaar, J., Williams, G. L., and Fuller, M.: Dinoflagellate cysts from the EoceneOligocene transition in the Southern Ocean: results from ODP Leg 189, in Proc. ODP, Sci. Results, 189, pp. 1-42, College Station, TX (Ocean Drilling Program), 2003.

Sluijs, A., Pross, J., and Brinkhuis, H.: From greenhouse to icehouse; organic-walled dinoflagellate cysts as paleoenvironmental indicators in the Paleogene, Earth-Sci. Rev., 68, 281-315, https://doi.org/10.1016/j.earscirev.2004.06.001, 2005.

Sluijs, A., Brinkhuis, H., Williams, G. L., and Fensome, R. A.: Taxonomic revision of some CretaceousCenozoic spiny organic-walled peridiniacean dinoflagellate cysts, Rev. Palaeobot. Palynol., 154, 34-53, https://doi.org/10.1016/j.revpalbo.2008.11.006, 2009.

Sluijs, A., Bijl, P. K., Schouten, S., Röhl, U., Reichart, G.-J., and Brinkhuis, H.: Southern ocean warming, sea level and hydrological change during the Paleocene-Eocene thermal maximum, Clim. Past, 7, 47-61, https://doi.org/10.5194/cp-7-472011, 2011.

Sluijs, A., Zeebe, R. E., Bijl, P. K., and Bohaty, S. M.: A middle Eocene carbon cycle conundrum, Nat. Geosci., 6, 429-434, https://doi.org/10.1038/ngeo1807, 2013.

Sømme, T. O., Helland-Hansen, W., and Granjeon, D.: Impact of eustatic amplitude variations on shelf morphology, sediment dispersal, and sequence stratigraphic interpretation: Icehouse versus greenhouse systems, Geology, 37, 587-590, https://doi.org/10.1130/G25511A.1, 2009.

Spofforth, D. J. A., Agnini, C., Pälike, H., Rio, D., Fornaciari, E., Giusberti, L., Luciani, V., Lanci, L., and Muttoni, G.: Organic carbon burial following the middle Eocene climatic optimum in the central western Tethys, Paleoceanography, 25, PA3210, https://doi.org/10.1029/2009PA001738, 2010.

Stacey, A., Mitchell, C., Nayak, G., Struckmeyer, H., Morse, M., Totterdell, J., and Gibson, G.: Geology and petroleum prospectivity of the deepwater Otway and Sorell basins: new insights from an integrated regional study, APPEA J., 51, 692-692, https://doi.org/10.1071/AJ10072, 2013. 
Steinthorsdottir, M., Vajda, V., Pole, M., and Holdgate, G.: Moderate levels of Eocene $p \mathrm{CO}_{2}$ indicated by Southern Hemisphere fossil plant stomata, Geology, 47, 914-918, https://doi.org/10.1130/G46274.1, 2019.

Stickley, C. E., Brinkhuis, H., McGonigal, K. L., Chaproniere, G. C. H., Fuller, M., Kelly, D. C., Nürnberg, D., Pfuhl, H. A., Schellenberg, S. A., Schoenfeld, J., Suzuki, N., Touchard, Y., Wei, W., Williams, G. L., Lara, J., and Stant, S. A.: Late CretaceousQuaternary biomagnetostratigraphy of ODP Sites 1168, 1170, 1171, and 1172, Tasmanian Gateway, edited by: Exon, N. F., Kennett, J. P., Malone, M. J., Ocean Drilling Program, College Station, TX, pp. 1-57, 2004a.

Stickley, C. E., Brinkhuis, H., Schellenberg, S. A., Sluijs, A., Röhl, U., Fuller, M., Grauert, M., Huber, M., Warnaar, J., and Williams, G. L.: Timing and nature of the deepening of the Tasmanian Gateway, Paleoceanography, 19, PA4027, https://doi.org/10.1029/2004PA001022, 2004b.

Stover, L. E. and Partridge, A. D.: Tertiary and Late Cretaceous spores and pollen from the Gippsland Basin, southeastern Australia, Proc. Roy. Soc. Victoria, 85, 237-286, 1973.

Sutherland, R., Collot, J., Bache, F., Henrys, S., Barker, D., Browne, G. H., Lawrence, M. J. F., Morgans, H. E. G., Hollis, C. J., Clowes, C., Mortimer, N., Rouillard, P., Gurnis, M., Etienne, S., and Stratford, W.: Widespread compression associated with Eocene Tonga-Kermadec subduction initiation, Geology, 45, 355-358, https://doi.org/10.1130/G38617.1, 2017.

Sutherland, R., Dickens, G. R., Blum, P., Agnini, C., Alegret, L., Asatryan, G., Bhattacharya, J., Bordenave, A., Chang, L., Collot, J., Cramwinckel, M. J., Dallanave, E., Drake, M. K., Etienne, S. J. G., Giorgioni, M., Gurnis, M., Harper, D. T., Huang, H.H. M., Keller, A. L., Lam, A. R., Li, H., Matsui, H., Morgans, H. E. G., Newsam, C., Park, Y.-H., Pascher, K. M., Pekar, S. F., Penman, D. E., Saito, S., Stratford, W. R., Westerhold, T., and Zhou, X.: Continental-scale geographic change across Zealandia during Paleogene subduction initiation, Geology, 48, 419-424, https://doi.org/10.1130/G47008.1, 2020.

Taylor, D. J.: Biostratigraphic Log - Latrobe No. 1 Bore, Department of Mines of Victoria, Melbourne, 1964.

Taylor, K. W. R., Huber, M., Hollis, C. J., HernandezSanchez, M. T., and Pancost, R. D.: Re-evaluating modern and Palaeogene GDGT distributions: Implications for SST reconstructions, Global Planet. Change, 108, 158-174, https://doi.org/10.1016/j.gloplacha.2013.06.011, 2013.

Thomas, D. J., Bralower, T. J., and Jones, C. E.: Neodymium isotopic reconstruction of late Paleocene-early Eocene thermohaline circulation, Earth Planet. Sci. Lett., 209, 309-322, https://doi.org/10.1016/S0012-821X(03)00096-7, 2003.

Thomas, M. K., Kremer, C. T., Klausmeier, C. A., and Litchman, E.: A Global Pattern of Thermal Adaptation in Marine Phytoplankton, Science, 338, 1085-1088, https://doi.org/10.1126/science.1224836, 2012.

Tickell, S. J., Abele, C., and Parker, G. J.: Palynology of the Eastern Otway Basin, Geological Survey of Victoria Unpublished Report (1993/18), 1993.

Torsvik, T. H., Van der Voo, R., Preeden, U., Mac Niocaill, C., Steinberger, B., Doubrovine, P. V., van Hinsbergen, D. J. J., Domeier, M., Gaina, C., Tohver, E., Meert, J. G., McCausland, P. J. A., and Cocks, L. R. M.: Phanerozoic polar wander, palaeogeography and dynamics, Earth-Sci. Rev., 114, 325-368, https://doi.org/10.1016/j.earscirev.2012.06.007, 2012.

Totterdell, J. M., Blevin, J. E., Struckmeyer, H. I. M., Bradshaw, B. E., Colwell, J. B., and Kennard, J. M.: A new sequence framework for the Great Australian Bight: starting with a clean slate, APPEA J., 40, 95-118, https://doi.org/10.1071/aj99007, 2000.

van der Ploeg, R., Selby, D., Cramwinckel, M. J., Li, Y., Bohaty, S. M., Middelburg, J. J., and Sluijs, A.: Middle Eocene greenhouse warming facilitated by diminished weathering feedback, Nat. Commun., 9, 2877, https://doi.org/10.1038/s41467-018-051049, 2018.

van Helmond, N. A. G. M., Sluijs, A., Reichart, G.-J., Damsté, J. S. S., Slomp, C. P., and Brinkhuis, H.: A perturbed hydrological cycle during Oceanic Anoxic Event 2, Geology, 42, 123-126, https://doi.org/10.1130/G34929.1, 2014.

van Helmond, N. A. G. M., Hennekam, R., Donders, T. H., Bunnik, F. P. M., de Lange, G. J., Brinkhuis, H., and Sangiorgi, F.: Marine productivity leads organic matter preservation in sapropel S1: palynological evidence from a core east of the Nile River outflow, Quat. Sci. Rev., 108, 130-138, https://doi.org/10.1016/j.quascirev.2014.11.014, 2015.

van Hinsbergen, D. J. J., de Groot, L. V., van Schaik, S. J., Spakman, W., Bijl, P. K., Sluijs, A., Langereis, C. G., and Brinkhuis, H.: A Paleolatitude Calculator for Paleoclimate Studies, PLoS ONE, 10, e0126946, https://doi.org/10.1371/journal.pone.0126946, 2015.

Villa, G., Fioroni, C., Pea, L., Bohaty, S., and Persico, D.: Middle Eocene-late Oligocene climate variability: Calcareous nannofossil response at Kerguelen Plateau, Site 748, Marine Micropaleontol., 69, 173-192, https://doi.org/10.1016/j.marmicro.2008.07.006, 2008.

Warnaar, J., Bijl, P. K., Huber, M., Sloan, L., Brinkhuis, H., Röhl, U., Sriver, R., and Visscher, H.: Orbitally forced climate changes in the Tasman sector during the Middle Eocene, Palaeogeogr. Palaeoclimatol. Palaeoecol., 280, 361370, https://doi.org/10.1016/j.palaeo.2009.06.023, 2009.

Weijers, J. W. H., Schouten, S., Spaargaren, O. C., and Sinninghe Damsté, J. S.: Occurrence and distribution of tetraether membrane lipids in soils: Implications for the use of the TEX86 proxy and the BIT index, Organ. Geochem., 37, 1680-1693, https://doi.org/10.1016/j.orggeochem.2006.07.018, 2006.

Weijers, J. W. H., Lim, K. L. H., Aquilina, A., Sinninghe Damsté, J. S. and Pancost, R. D.: Biogeochemical controls on glycerol dialkyl glycerol tetraether lipid distributions in sediments characterized by diffusive methane flux, Geochem. Geophy. Geosy., 12, Q10010, https://doi.org/10.1029/2011GC003724, 2011.

White, J.: Composite Well Log Latrobe No.1 Water Bore, Department of Mines of Victoria, Melbourne, 1963.

Williams, G. L., Damassa, S. P., Fensome, R. A., and Guerstein, G. R.: Wetzeliella and its allies - the 'hole' story: a taxonomic revision of the Paleogene dinoflagellate subfamily Wetzelielloideae, Palynology, 39, 289-344, https://doi.org/10.1080/01916122.2014.993888, 2015.

Williams, G. L., Damassa, S. P., Fensome, R. A., and Guerstein, G. R.: A response to "Comment to Wetzeliella and its allies - the "hole" story: a taxonomic revision of the Paleogene dinoflagellate subfamily Wetzelielloideae by Williams et al. (2015)", Palynology, 41, 430-437, https://doi.org/10.1080/01916122.2017.1283367, 2017a. 
Williams, G. L., Fensome, R. A., and MacRae, R. A.: The Lentin and Williams Index of Fossil Dinoflagellates 2017 Edition, available at: https://palynology.org/wp-content/uploads/2017/ 01/AASP-Contribution-Series-No.48.pdf (last access: 18 August 2020), 2017b.

Williams, S. E., Whittaker, J. M., Halpin, J. A., and Müller, R. D.: Australian-Antarctic breakup and seafloor spreading: Balancing geological and geophysical constraints, Earth-Sci. Rev., 188, 4158, https://doi.org/10.1016/j.earscirev.2018.10.011, 2019.

Wrenn, J. H. and Beckman, S. W.: Maceral, Total Organic Carbon, and Palynological Analyses of Ross Ice Shelf Project Site J9 Cores, Science, 216, 187-189, https://doi.org/10.1126/science.216.4542.187, 1982.

Wrenn, J. H. and Hart, G. F.: Paleogene dinoflagellate cyst biostratigraphy of Seymour Island, Antarctica, Geol. Soc. Am. Memoirs, 169, 321-448, https://doi.org/10.1130/MEM169p321, 1988.

Zachos, J. C., Dickens, G. R., and Zeebe, R. E.: An early Cenozoic perspective on greenhouse warming and carbon-cycle dynamics, Nature, 451, 279-283, https://doi.org/10.1038/nature06588, 2008.
Zhang, Y. G., Zhang, C. L., Liu, X.-L., Li, L., Hinrichs, K.U., and Noakes, J. E.: Methane Index: A tetraether archaeal lipid biomarker indicator for detecting the instability of marine gas hydrates, Earth Planet. Sci. Lett., 307, 525-534, https://doi.org/10.1016/j.eps1.2011.05.031, 2011.

Zinsmeister, W. J.: Biogeographic significance of the late Mesozoic and early Tertiary molluscan faunas of Seymour Island (Antarctic Peninsula) to the final breakup of Gondwanaland, in Historical Biogeography, Plate Tectonics, and the Changing Environment, edited by: Gray, J., Boucot, A. J., Oregon State University, Corvallis, pp. 349-355, 1979.

Zwiep, K. L., Hennekam, R., Donders, T. H., van Helmond, N. A. G. M., de Lange, G. J., and Sangiorgi, F.: Marine productivity, water column processes and seafloor anoxia in relation to Nile discharge during sapropels S1 and S3, Quat. Sci. Rev., 200, 178190, https://doi.org/10.1016/j.quascirev.2018.08.026, 2018. 